DEPARTMENT OF THE INTERIOR

U.S. GEOLOGICAL SURVEY

\title{
Specific gravity data from granitic rocks of the southern Sierra Nevada, California
}

\author{
by \\ Donald C. Ross \\ U.S. Geological Survey ${ }^{1}$
}

Open-File Report $88-72$

This report is preliminary and has not been reviewed for conformity with U.S. Geological Survey editorial standards and stratigraphic nomenclature.

1Menlo Park, California

1988 
CONTENTS

INTRODUCTION.........................

NEASUREMENTS ........................

INTERPRETATIONS OF SPECIFIC GRAVITY DATA......2

ACINOWLEDGHENTS ..........................

KEFERETCES CITED.....................II 


\section{ILIUSTRATIONS}

\section{Figures}

1. Specific gravity distribution by rock type of 1531 samples from the southern Sierra Nevada, California.

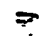

2. Specific gravity distribution for selected individual plutons of the southern Sierra Nevada, California.

2-A. Granite

2-B. Granodiorite

2-C. Tonalite

3. Specific gravity plotted against color index for samples from the southern Sierra Nevada, California.

3-A. Composite

3-B. Granite

3-c. Granodiorite

3-D. Tonalite

3-E. Quartz diorite

4. Average specific gravity plotted against average color index for each granitic unit of the southern Sierra Nevada, California.

5. Specific gravity plotted against modal minerals for chemically analyzed samples, southern Sierra Nevada, California.

5-1. Plagioclase

5-2. K-feldspar

5-3. Quartz

5-4. Biotite

5-5. Hornblende

5-6. Color index (biotite plus hornblende)

6. Specific gravity plotted against silica content for chemically analyzed samples, southern Sierra Nevada, California. 
Tables

1. Supplement to specific gravity determinations recorded in U.S.G.S. Open-File Report 87-373 (Ross, 1987a). Table keyed to units and modāi samples in that report.

$$
?
$$

2. Computed specific gravity, by rock type, using modes and average mineral specific gravity.

3. Comparison of average measured and computed specific gravity for selected granitic units. 


\section{INTRODUCTION}

In the course of a geologic study of granitic and metamorphic rọcks of an extensive area of the southern Sierra Nevada, California (north to $1 \overline{\mathrm{z}} \mathrm{t} 3600$ ' N), more than 1500 granitic samples have been collected. The bulk specific gravity of most of these granitic samples has been recorded in modal tables in Ross (1987a). The specific gravity of other samples is recorded here (Table 1) and keyed to geologic units and index maps in Ross (1987a). In addition, the specific gravity and color index of about 100 samples collected in 1987 are used in the various plots of this report, but the data are as yet unpublished.

Specific gravity determinations have been made on many granitic specimens in the central sierra Nevada as one of the parameters measured in the course of regional geologic investigations. These specific gravity measurements also have been used to support gravity geophysical studies (Oliver, 1977), and more recently in studies of the internal structure and depth of the sierra Nevada batholith (Oliver, and others, 1987). The specific gravity data from the southern Sierra Nevada are intended to further supplement these studies.

This report will summarize graphically the specific gravity distribution for all samples and for each rock type (Fig. 1). In addition the distribution of specific gravity is shown for some of the larger plutons (Fig. 2 ). Data on the character and distribution of the granitic units mentioned throughout this report can be found in a test accompanying a generalized geologic map at a scale of 1:250,000 for the southern Sierra Nevada (Ross, 1987b).

\section{MEASUREMENTS}

Specific gravity determinations for those granitic samples recorded in Ross (1987a) were by the lever arm balancing method where the specific gravity value is interpreted from a graduated scale on the balance beam. The other 
specific gravity values reported here and those yet unpublished were determined by a somewhat more advanced method of measuring samples in air and water with a digital read out of specific gravity. Practice suggests that the latter method is more accurate because it reduces the effect of minute cracks and surface porerspace (H.W. Oliver, written commun., 1987.)

\section{INTERPRETATION OF SPECIFIC GRAVITY DATA}

A simplistic assumption is commonly made (or assumed) in studying granitic terranes that a sawed surface is representative of a hand specimen and that a hand specimen is representative of a granitic body. This assumption is, of course, far from true in the real world where heterogeneity of granitic bodies, even when they "look" homogeneous, is a fact of life. Any determination of specific gravity, color index, silica content, and all other "facts" from a hand specimen are point sources that give a piece of information about a granitic body, but what it means for the body as a whole is open to much interpretation. However, large numbers of determinations do give groupings and linear trends that define characteristics of a body as the figures in this report show. The "spread" of data in many of the following figures can be due in part to misreading of specific gravity results or inaccuracy in point counting, but most spread is probably caused by weathered samples, rock pore space, or the heterogeneity inherent in granitic rocks.

A plot of the specific gravity for the entire granitic sample population of the southern Sierra Nevada is shown by a histogram (fig. 1). This same figure also shows the distribution of specific gravity by rock type. It shows a predictable increase in specific gravity from granite to quartz diorite that is largely a function of the varying mafic mineral content of these rocks. 
Histograms of specific gravity distribution for selected plutons (fig. 2) reflect the strong influence of mafic mineral content (color index) of the various bodies. Quartz also influences the specific gravity, but quartz variation is generally not as obvious in hand specimens of granitic focks, and only becomes evident in modal analyses (fig. 5 ).

The granite plots (Fig. 2-A) show that the darker Kern River mass has distinctly higher specific gravities than the coarser, more felsic Tejon Lookout mass. The Kern River mass also has a distinctly wide spread of specific gravity values reflecting its more variable nature. In contrast the Tejon Lookout specific gravity values are more tightly bunched, indicating its more homogeneous nature. The granodiorite bodies (Fig. 2-B) likewise show distinct specific gravity distribution patterns. For example, in the field and from petrographic studies, the Lebec and Gato-Montes masses were considered correlative. The similar pattern of the specific gravity distribution of the two bodies certainly supports the postulated correlation. The other granodiorite masses plotted all have patterns separable from the Lebec and GatorMontes masses, and generally separable from each other. Similarly, the selected tonalite masses (Fig. 2-C) show a variety of patterns. Note that the texturally and mineralogically similar Bear valley Springs and Dunlap Meadow masses have rather similar specific gravity distribution patterns (Fig. 2-C). The other tonalite masses have distinctly different and separable pattern of specific gravity distribution. None of the above observations are surprising, and, in fact, they fairly obviously follow, based on extensive modal analyses and petrographic study. Nevertheless, they point out the value of specific gravity alone in correlating and separating granite masses. This might be particularly valuable in a rapid reconnaissance study where modal and petrographic studies were limited.

The general assumption of a positive correlation between specific gravity 
and color index (in these rocks, basically the sum of biotite and hornblende) is graphically presented in Fig. 3. Although there is some spread of data for each rock type, there is a remarkable overall alignment, particularl $\dot{y}$ on the composite plot (fig. 3A). The quartz diorite field is rather diffuse reflecting the wide range of color index values in this heterogeneous group of rocks. Nevertheless, though diffuse, the quartz diorite field still shows a fairly good linear trend.

When the color index average is plotted against the average measured specific gravity for each granitic unit (Fig. 4) the field is considerably tightened, but the more diffuse pattern of the quartz diorites is still obvious. The quartz diorites in general are somewhat anomalous; four quartz diorite units seem to be related to the mafic gneissic complex in the sierran tail, and the other two are Triassic. Not surprisingly, they do not conform to the sharp linear pattern of the granites, granodiorites, and tonalites. The accuracy of a color index is dependent on the modal determination of bionome and hornblende, generally the only significant mafic constituents. Although the distinction between hornblende and biotite is difficult to determine in the modal analysis of some rocks, the total of the two minerals (color index) is generally easy to determine.

Specific gravity measures a property of a whole hand specimen of whatever size you choose to haul. Nevertheless, inhomogeneity and particularly weathered condition make an individual specific gravity determination only an approximation - a local spot in a body. Nevertheless, a large number of samples measured for both specific gravity and color index do make remarkably linear trends (Figs. 3, 4, and 5) and provide valuable information on the character of rock bodies and, in combination with gravity data, give an indication of their depth extent (0liver and others, 1987).

For the more than 100 chemically analyzed samples, plots show the relation of specific gravity to the amount of the various modal minerals (Fig. 
5). Samples selected for chemical analysis were chosen for their freshness (weathered rinds were taken off before the samples were submitted for a chemical analysis). Therefore the trend of the plot of color index against specific gravity should be somewhat better defined than the plot whe all the modal samples are used (fig. 3-A). Nevertheless there is still substantial spread in figure 5-6. Particularly noticeable in the plot are a number of points considerable lower in specific gravity than would be predicted from the color index. This suggests that these specimens were not as fresh as presumed, or that minute pore spaces and cracks have lowered the specific gravity. Two tonalite samples on several plots had anomalously high measured specific gravities of 2.91 and 2.89 , considering their color indices of 28 and 24. A re-run of the specific gravities for these samples gave reduced values of 2.78 and 2.76 . This points out one of the advantages of having a large mass of data - anomalous points suggest some problem; in this case a couple of misdetermined specific gravity readings. The re-run specific gravities nestled nicely back into the mass of data on the relevant plots.

Each modal mineral amount for the chemically analyzed samples was plotted against specific gravity (Fig. 5-1 through 5). The plot of each mineral makes a readily identifiable trend. However, both plagioclase (Fig. 5-1) and K-feldspar (Fig. 5-2) make rather diffuse trends. Quartz makes a rather striking trend from 10 to 20 percent in the heavier rocks to 20 to 30 percent in the lighter rocks (Fig. 5-3). I, for one, was surprised at the pronounced "tilt" of this trend. From casual field and petrographic observation I thought many of the tonalites had as much quartz as the granites. This is true for some samples, but the overall trend for all samples clearly shows a pronounced enrichment in quartz in the granites. The amounts of biotite (Fig. 5-4) and hornblende (Fig. 5-5) show the best correlation with specific gravity: possibly biotite has a slightly tighter trend. Samples from the Antimony Peak and Tehachapi Mountain units, closely related to the mafic 
gneiss complex, are notably anomalous in these plots. The color index (biotite plus hornblende) plot against specific gravity (Fig. 5-6) shows a good linear trend and reflects the dominant effect of the mafic minerals on the specific gravity of these rocks. Color index is very easy to determine from a stained slab (no worry about biotite and hornblende distinction) and seemingly (from these rocks anyway) would make prediction of the specific gravity relatively accurate without a separate measurement. Also, it appears from these plots (Fig. 5-1 through 6 ) that biotite amount is the single best "indicator" of specific gravity of all the individual major minerals.

All these plots, even biotite, have enough spread so that any one sample would have only limited correlative value. For example, rocks containing from 6 to 14 percent biotite all have measured specific gravities of 2.70, and samples containing 10 to 21 percent biotite all have specific gravities of 2.75. Some of these variations probably reflect the difficulty in accurately reading the specific gravity from the "balance point" in the older measurements. Also an everpresent problem is the assumption that a mode from a sawed and stained surface accurately measures the mineral content of a hand specimen. Inaccuracies of modes due to sporadic distribution of minerals are particularly a problem in smaller slabs. Nevertheless, the trend line for a large number of samples is meaningful for correlating modal biotite and specific gravity (fig. 5-4).

The chemically analyzed samples can also be used to test the relation (interdependence) of specific gravity, and silica content. Specific gravity plotted against silica content makes a good linear belt with only a few notably anomalous points (Fig. 6). The trend is consistent enough to enable one to grossly predict the silica value of a sample where specific gravity was known, and vice versa.

Specific gravities can also be computed relatively accurately for these rocks using the modal mineral content and an average specific gravity for the 
major minerals. The granitic rocks of the southern sierra Nevada are dominated by plagioclase, quartz, and R-feldspar whose specific gravities are relatively consistent (Deer et al., 1965). Choosing average values for biotite and hornblende is not nearly as easy as they are both characteristically variable and not many specific gravity determinations are available. The nearest determinations are from biotites and hornblendes from the California Coast and Transverse Ranges near the San Andreas fault (Dodge and Ross, 1971). The mafic mineral specific gravities are mostly from tonalites and some granodiorites whose relation to the granitic rocks of the southern Sierra Nevada is presently controversial. The biotite and hornblende are optically and physically similar to the mafic minerals in the southern sierra Nevada. The specific gravities of the biotites (9 samples) range from 2.97 to 3.07 and average 3.03. The hornblende ( 8 samples) range from 3.21 to 3.27 and average 3.24 .

The average specific gravity of each rock type was calculated using the above discussed mineral specific gravities and the mineral modal averages (Table 2). Some caution must be exercised in using the modal averages, as bodies of widely disparate sizes are averaged. For example, in the granodiorites some bodies only cover from 1 to $10 \mathrm{Km}^{2}$, whereas the Castle Rock body covers $890 \mathrm{~km}^{2}$. Likewise in the tonalites, some bodies cover less than $10 \mathrm{Km}^{2}$ whereas the Bear valley springs unit covers $875 \mathrm{~km}^{2}$. To test the effect of this difference in areal coverage, a weighted specific gravity was computed to compare with the modal average specific gravity for each rock type. Weighting for size made no significant difference in specific gravity for granodiorite and tonalite which have the biggest discrepancy in unit sizes. A small 0.01 difference was noted in granite and quartz diorite presumably chiefly from differences in biotite content in the weighted computations. The granite difference appears larger because of rounding. The actual difference is $0.004,(2.644$ to 2.648$)$. Likewise, without rounding, the 
quartz diorite difference is only $0.001(2.805$ to 2.804$)$. For practical purposes, for these rocks, weighting makes no difference in the specific gravity computations.

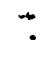

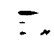

For the major plutonic units the measured average specific gravity of the modal samples was compared with a computed specific gravity using the modal averages for each mineral multiplied by assumed average specific gravities for each mineral (Table 2). In almost all cases the measured specific gravity was 0.01 to 0.03 lower than that computed (Table 3 ). Probably the major cause of this difference is the weathered nature of assumed "fresh" samples. The Bishop Ranch unit emphasizes this point. Although an effort was made to collect relatively fresh material, the Bishop Ranch is notoriously weathered and the measured specific gravity was not surprisingly 0.05 lower than the computed value. Other reasons for a difference between calculated and measured specific gravity are differences between assumed and actual specific gravities for biotite and hornblende, and also the probability of tiny fractures and minute pore spaces in even the most fresh-appearing rocks. Given the well known variation in chemical composition and specific gravity of biotite and hornblender-notable chemical wastebaskets-rwe should not assume too much from a chosen average specific gravity. In summary, the granites are generally the most weathered, but they have low color indexes and the difference between computed and measured specific gravity is mostly due to the weathering. Granodiorites, generally, have more closely comparable computed and measured values, reflecting their generally fresher condition, and, although they have higher color indexes, most are hornblende poor and the specific gravity is strongly influenced by the quartz and feldspar contents whose specific gravities are more constant. Tonalites and quartz diorites overall have the greatest differences between measured and computed specific gravity for reasons not yet understood. Nevertheless, there is a general consistency to the values and for the southern sierra Nevada a specific 
gravity computed from average mineral specific gravities seems to be about 0.02 higher than a specific gravity measured by the "immersion method". The calculated specific gravity from the mode is probably somewhat equivalent to the "grain density", which does not take into account "porosity" in the form of tiny fractures in the measured samples. In most granitic rocks, long immersion in water will somewhat raise the specific gravity, indicating that even fresh granitic rocks have some porosity. This is at least in part (maybe in large part) the reason for discrepancies between measured and calculated specific gravities. 
I want to thank Meade Norman, Hector Villalobos, Jenny Metz, Deborah Goaldman, and Steve Glass for the specific gravity determinations. Small recompense for this repetitious, laborious work! Also, much thanks to Meade, Hector, Jenny, and Deborah for performing the tedious modal analyses on many of these rocks. 
REFERFNCES CITED

Deer, W.A., Howie, R.A., and Zussman, J., 1965, Rock-forming minerals: Iongmans, Green and Co. Ltd, Iondon, England.

Dodge, F.C.W., and Ross, D.C., 1971, Coexisting hornblendes and biotites from granitic rocks near the San Andreas fault, California: Journal of Geology, v.79, no.2, p.158-172.

oliver, H.W., 1977, Gravity and magnetic investigations of the sierra Nevada batholith: Geological Society of America Bulletin, v. 77, p. $445-461$

Oliver, H.W., Moore, J.G., and Sikora, R.F., 1987, Internal structure and depth of the sierra Nevada batholith, California, from specific gravity and gravity data (Extended Abstract): International symposium on Petrogenesis and Mineralization of granitoids, Abstracts with Programs. Ross, D.C., 1987a, Granitic rock modal data from the southern Sierra Nevada, California: U.S. Geological survey Open-File Report 87-373, $276 \mathrm{p}$.

Ross, D.C., 1987b, Generalized geologic map of the basement rocks of the southern Sierra Nevada, California: U.S. Geological Survey Open-File Report $87-276,28 \mathrm{p} .$, scale 1:250,000 

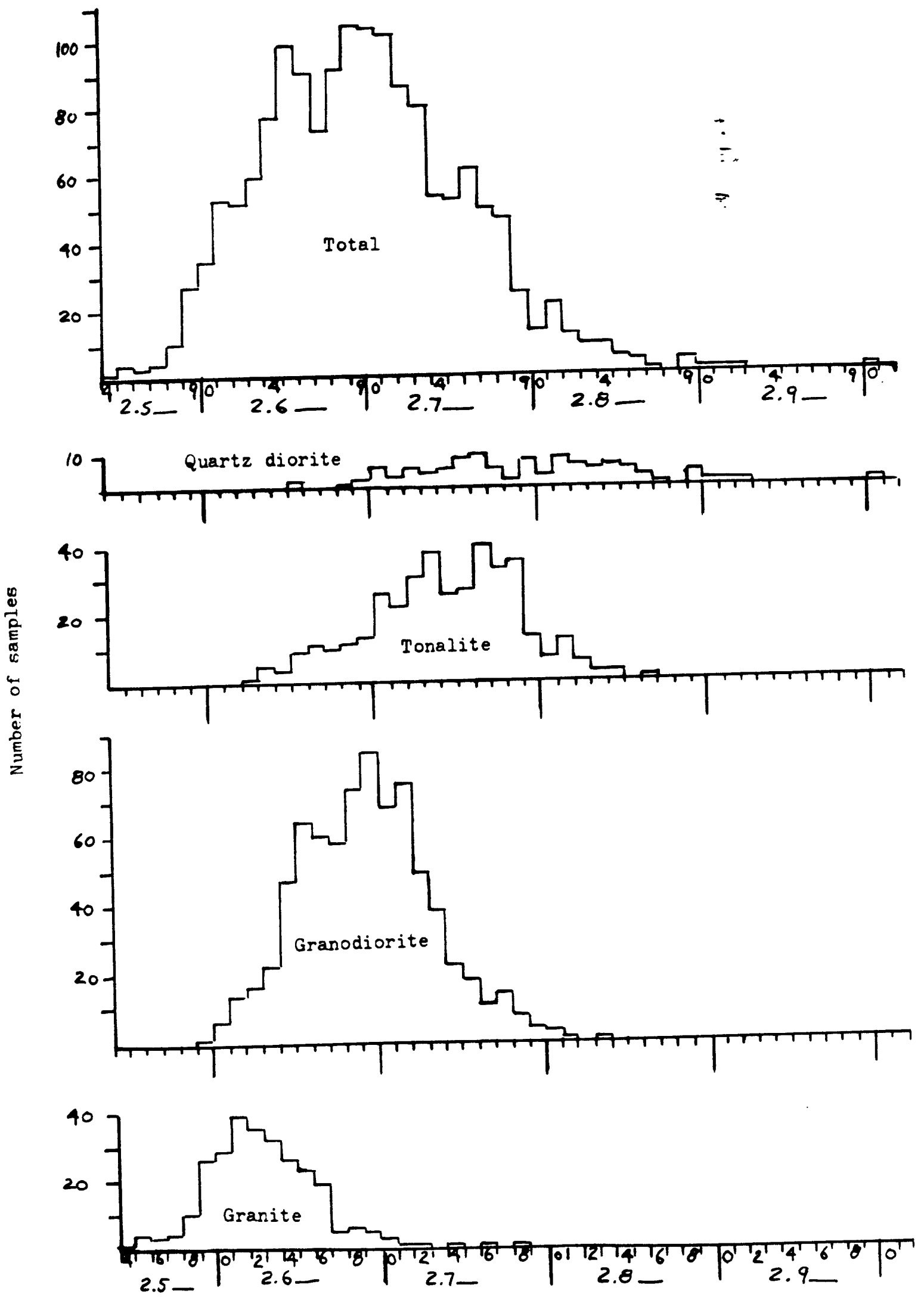

Specific gravity in grams $/ \mathrm{cc}^{3}$

Figure 1. Specific gravity distribution by rock type of 1531 granitic samples from the southern Sierra Nevada, California

$-12-$ 


$$
\begin{aligned}
& \square \\
& =
\end{aligned}
$$

Figure 2. Specific gravity distribution for selected individual plutons of the southern Sierra Nevada, California

2-A. Granite

2-B. Granodiorite

2-C. Tonalite 
GRANITE

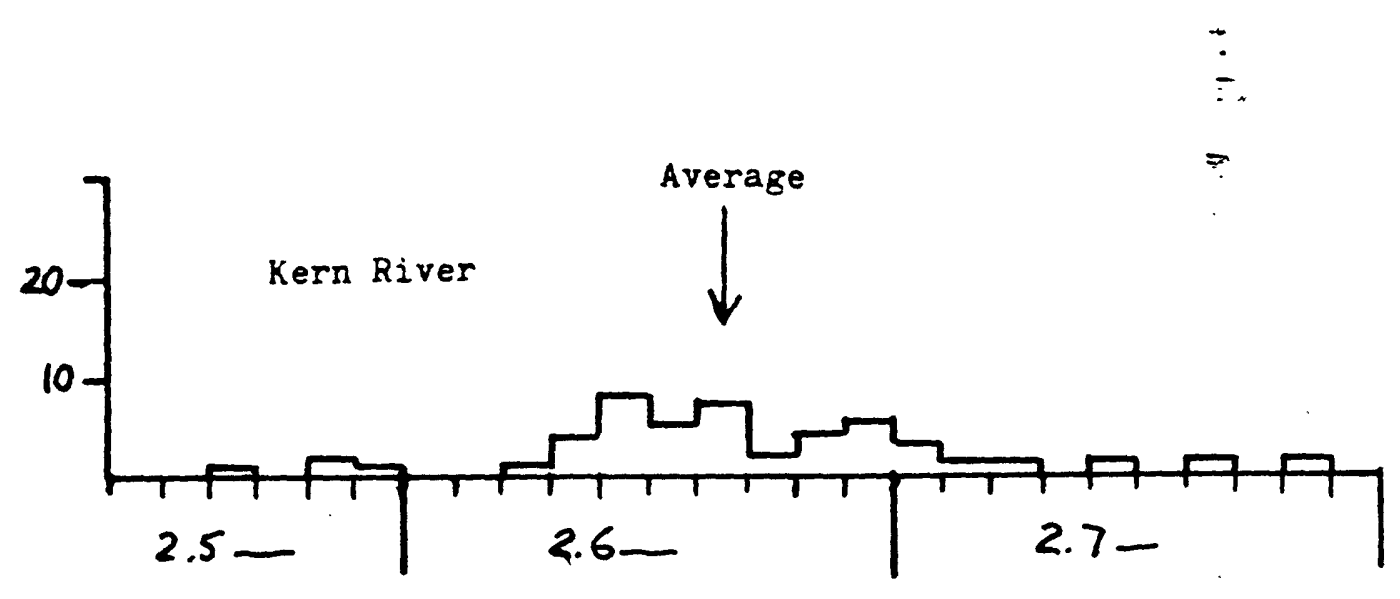

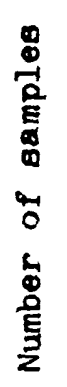
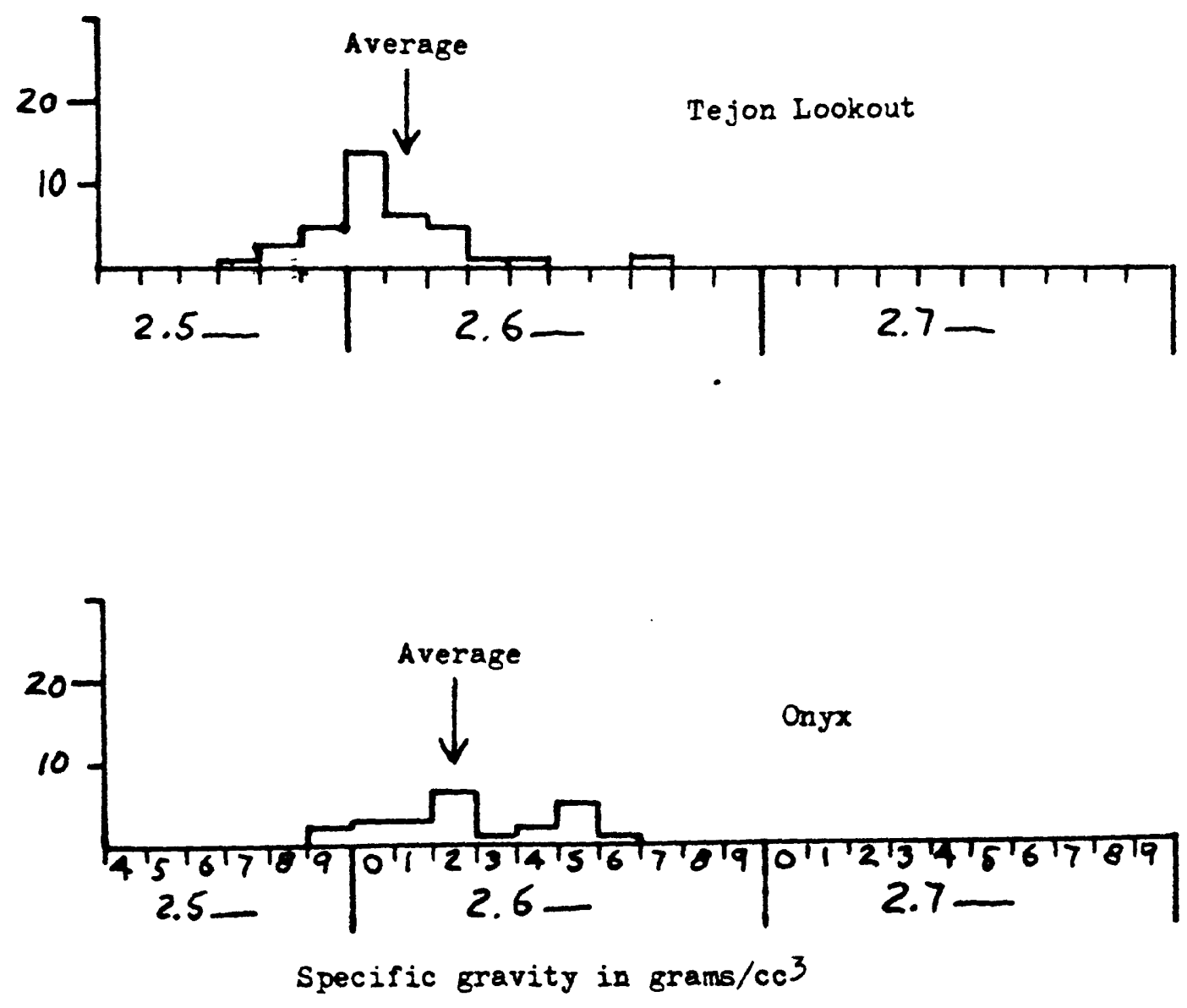

Figure 2-A. 

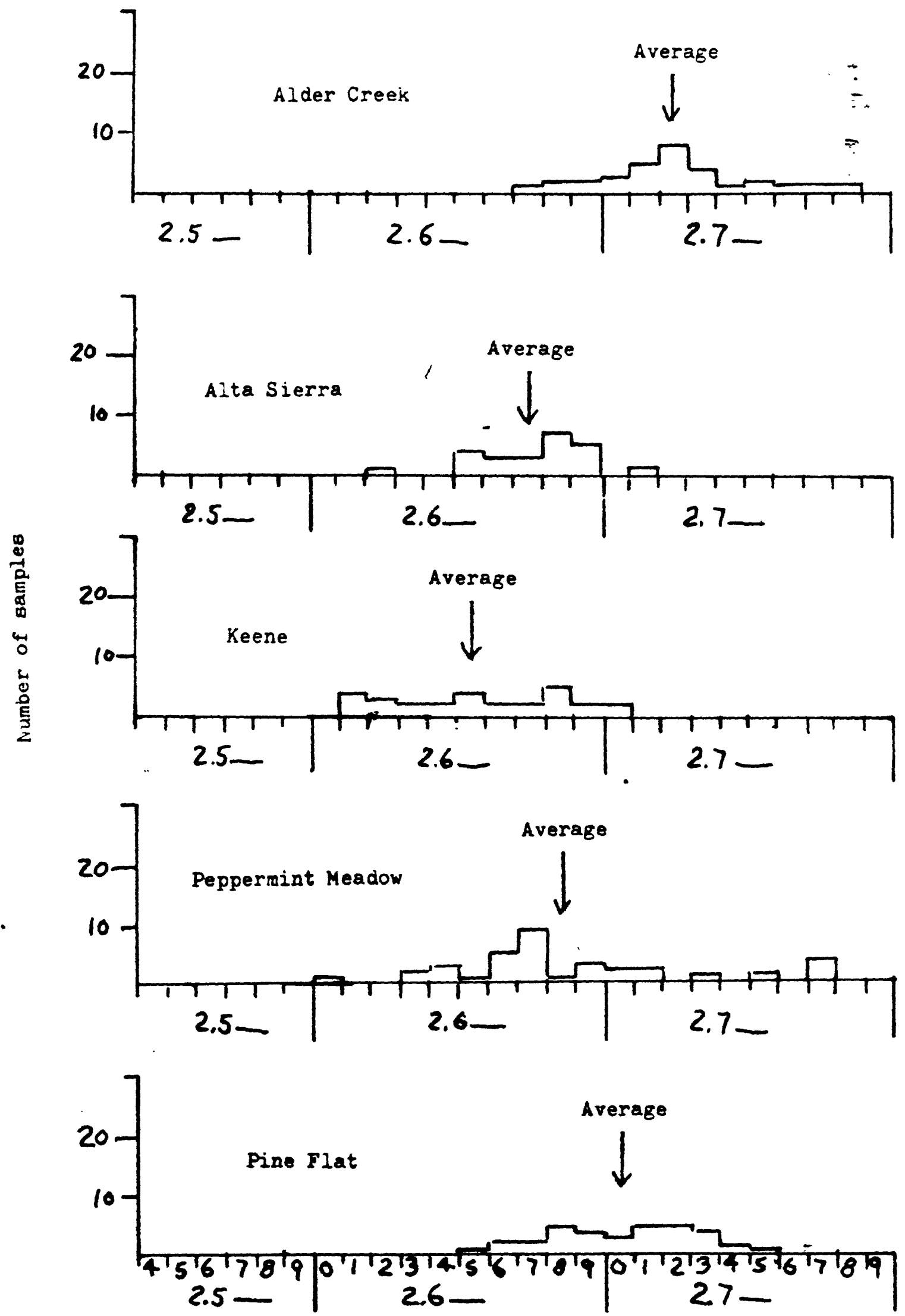

$$
\text { Specific gravity in grams/cc }{ }^{3}
$$

Figure 2-8. $\quad-15-$ 
GRANODIORITE (CONT.)
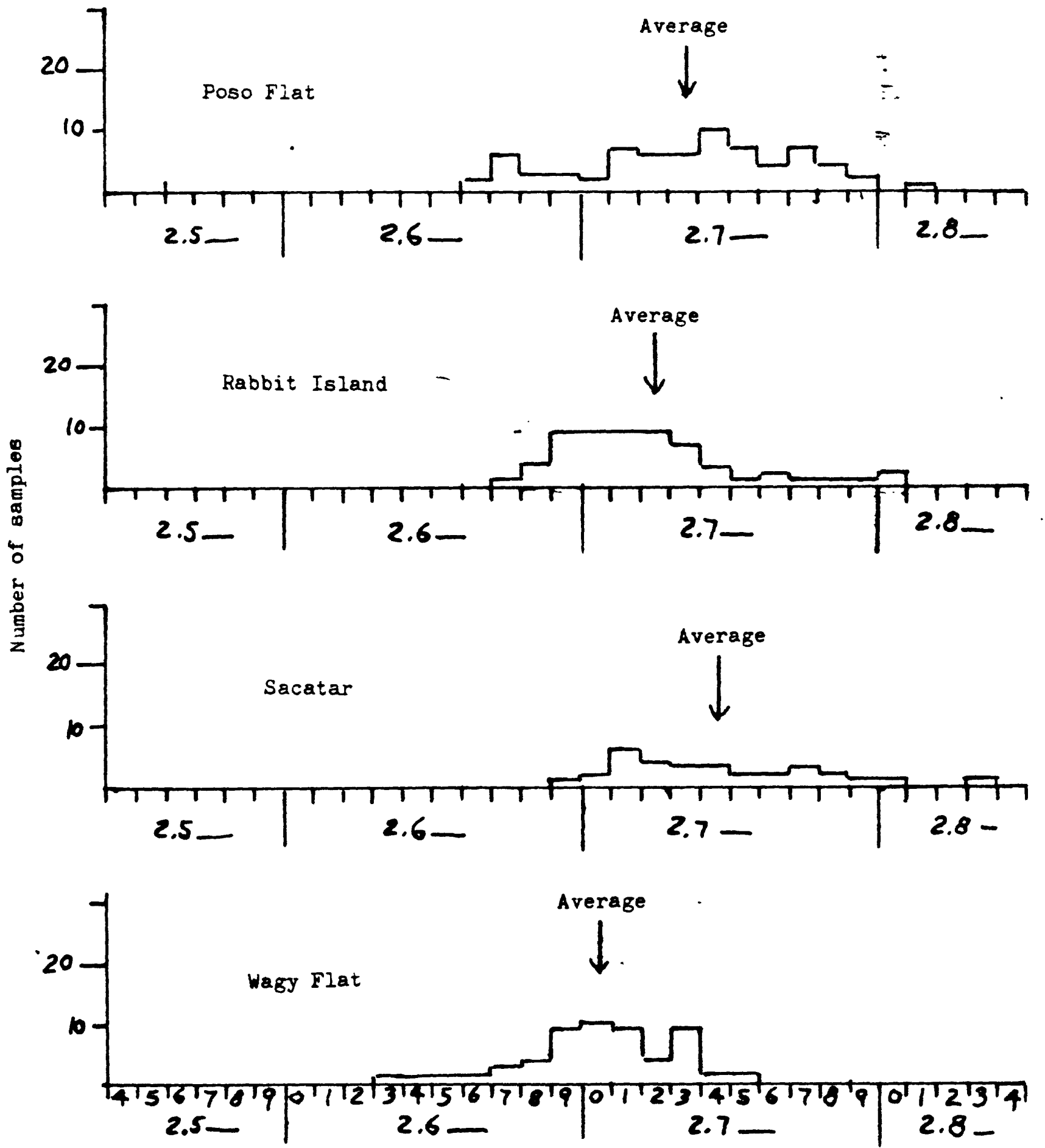

Specific gravity in grams/cc 3

Figure 2-B. 
GRANODIORITE (CONT.)
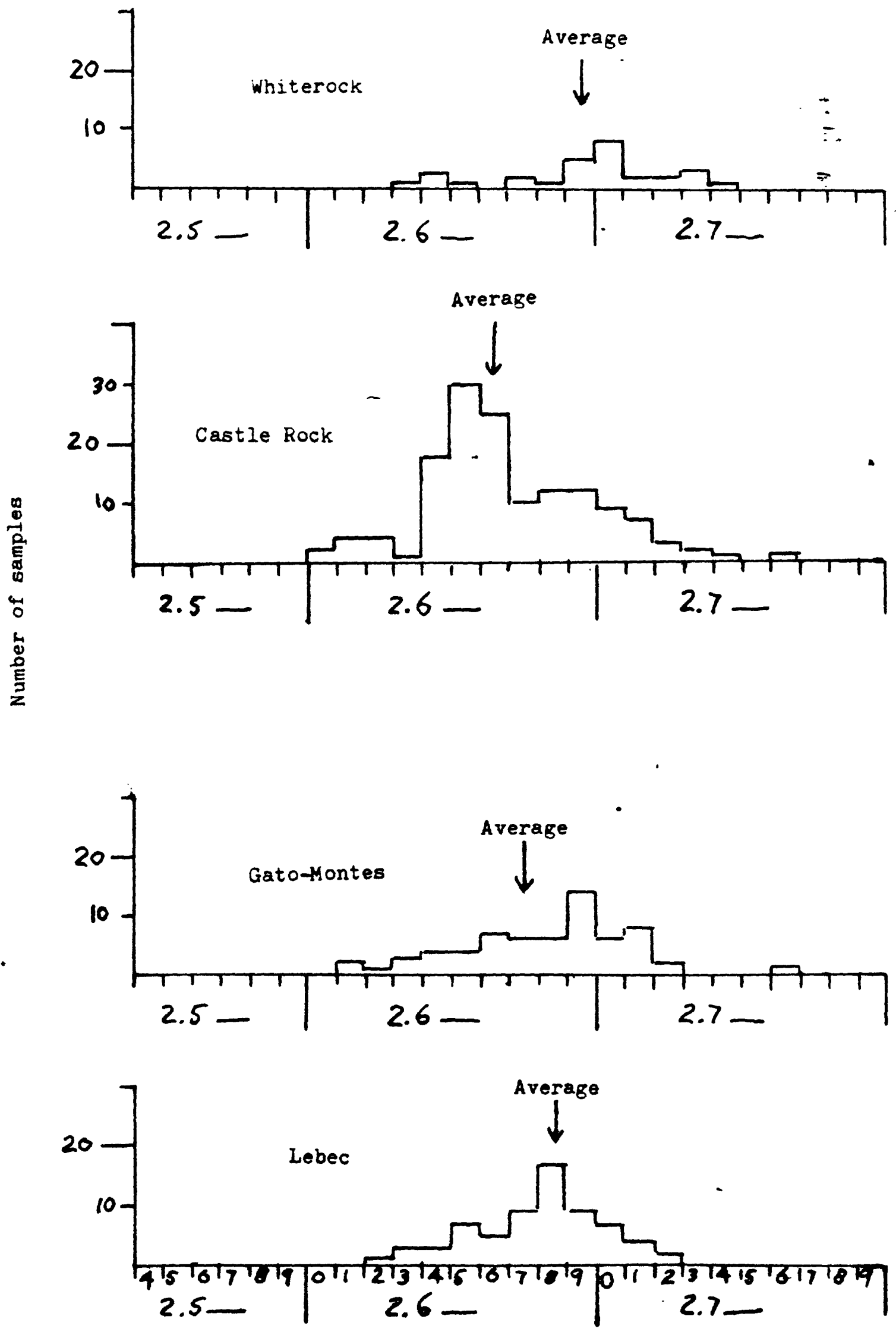

Figure 2-B.

Specific gravity in grams/ce 3 

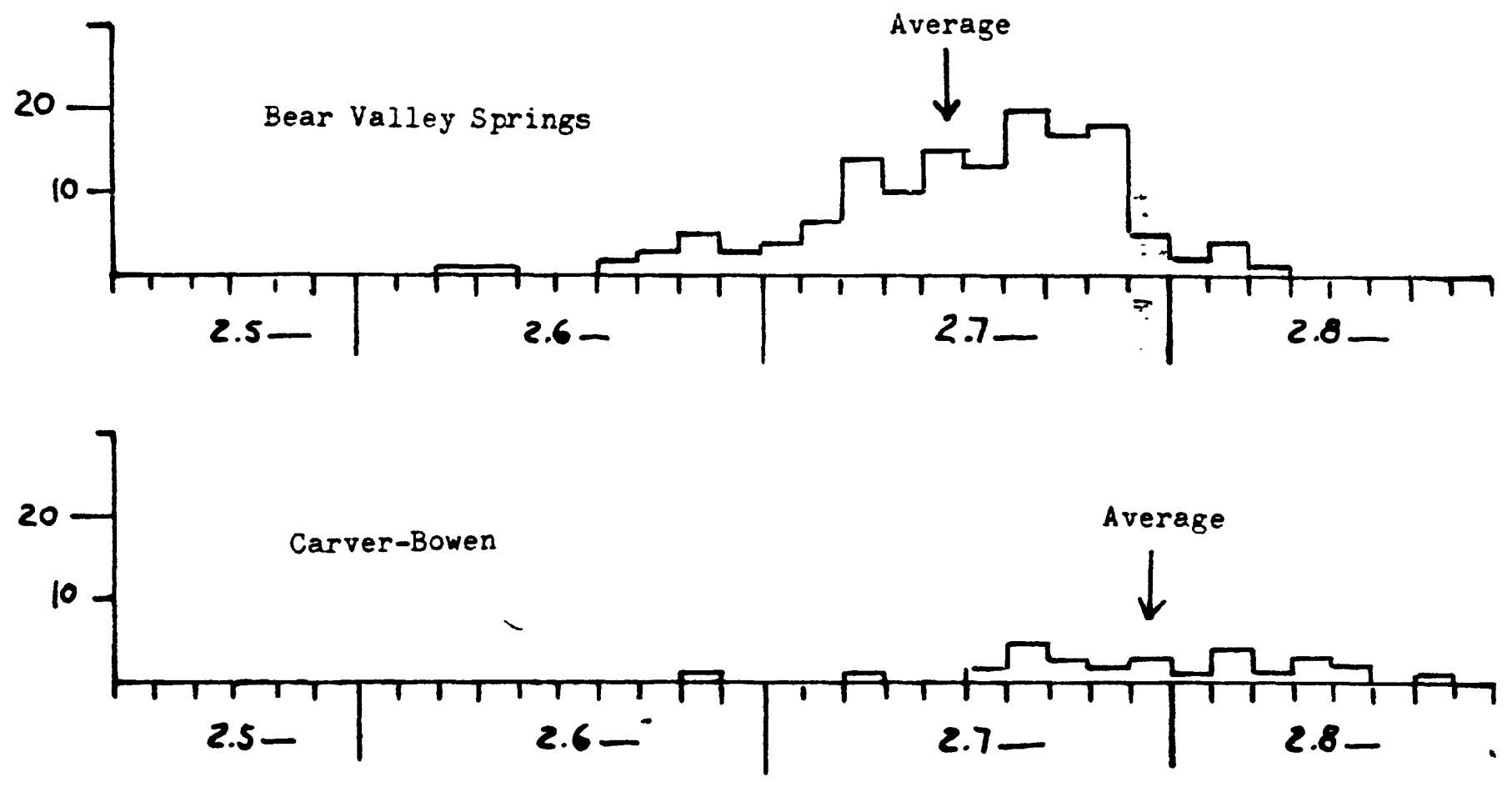

造
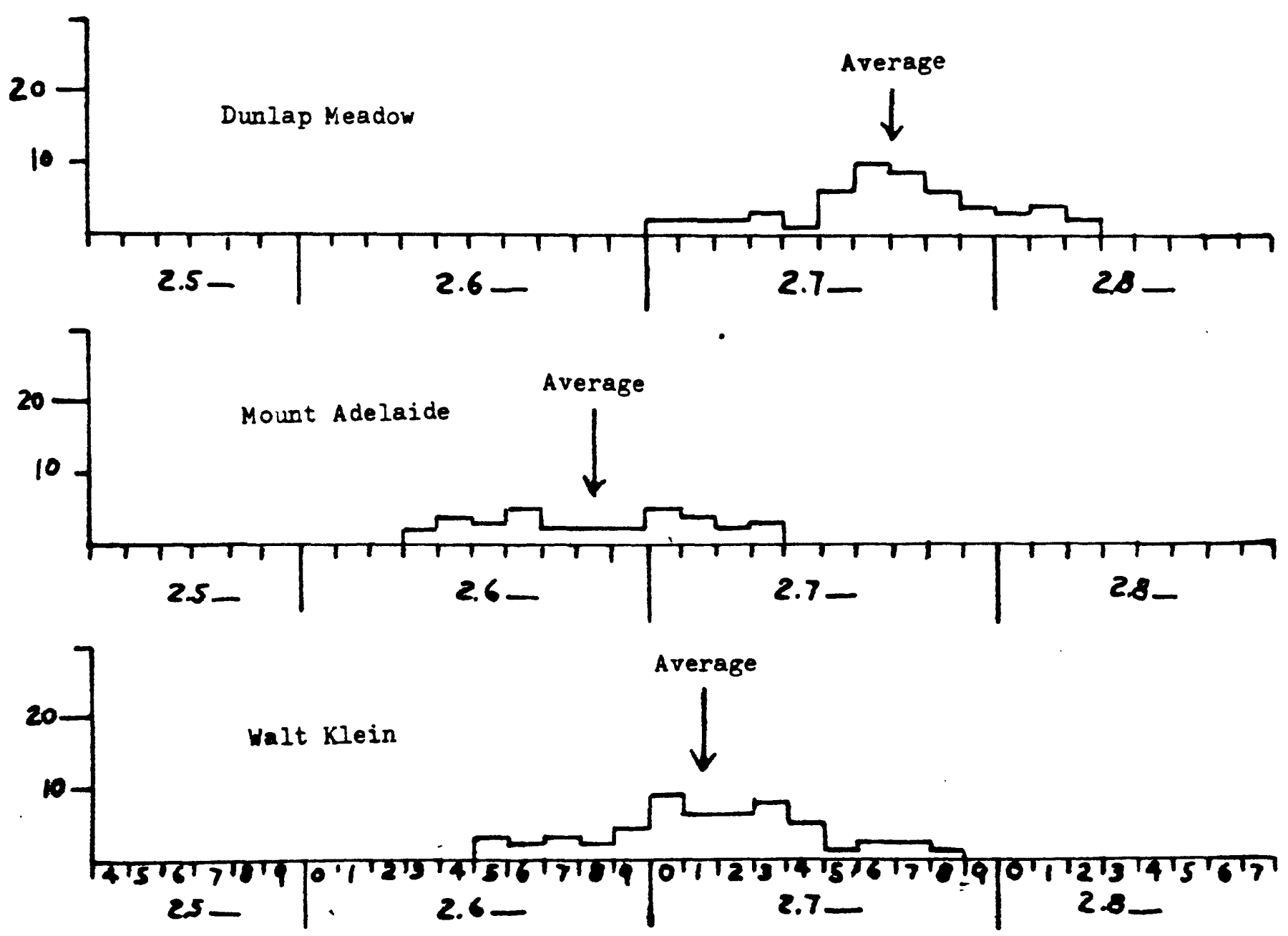

Figure $2-C$.

Specific gravity in grams/cc 3

$$
-18-
$$


1

Figure 3. Specific gravity plotted against color index for samples from the southern Sierra Nevada, California.

A. Composite (all samples)

B. Granite samples

C. Granodiorite samples

D. Tonalite samples

E. Quartz diorite samples 


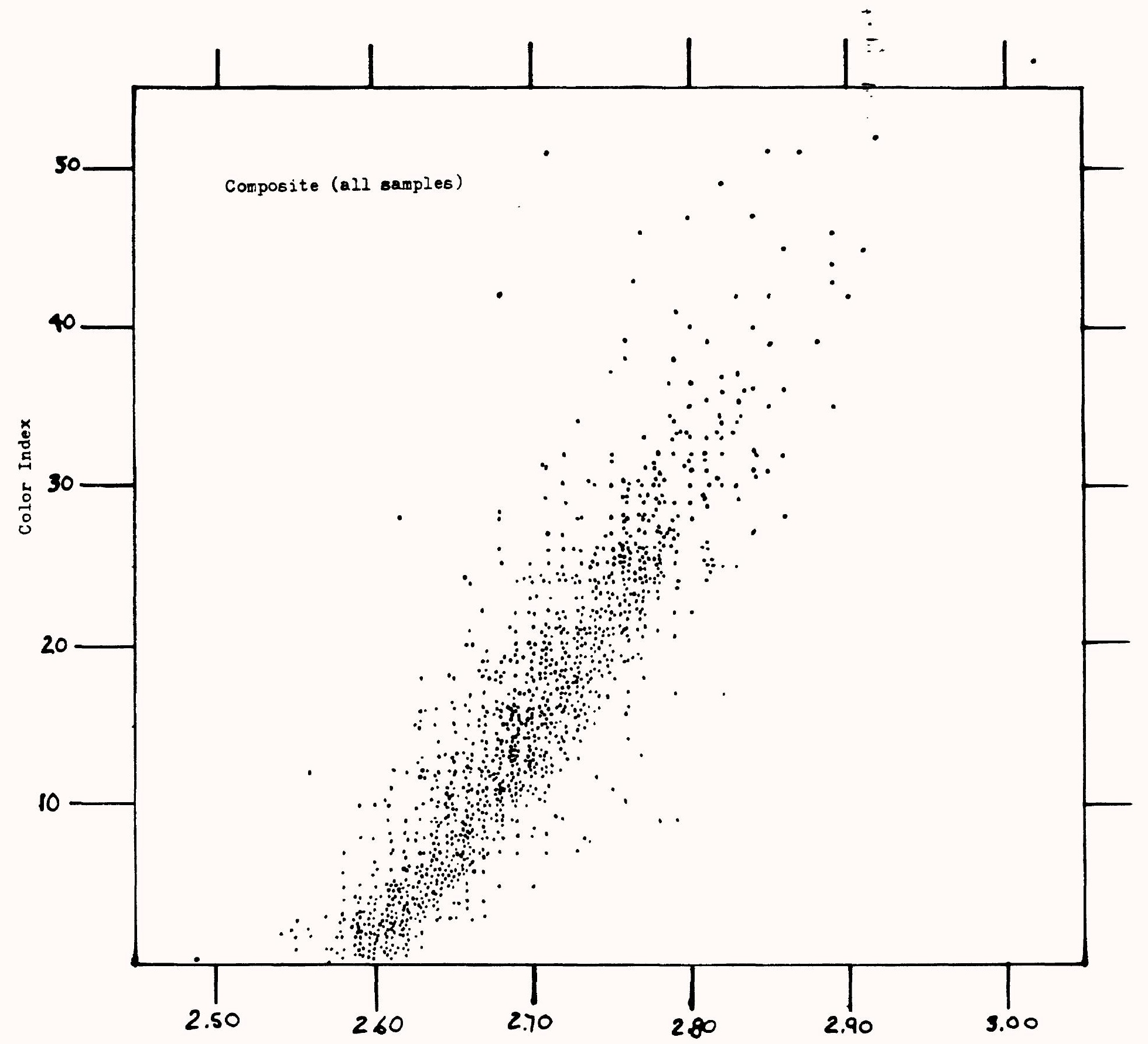

Specific gravity in grams $/ \mathrm{cc}^{3}$

Figure 3-A

$$
-20-
$$




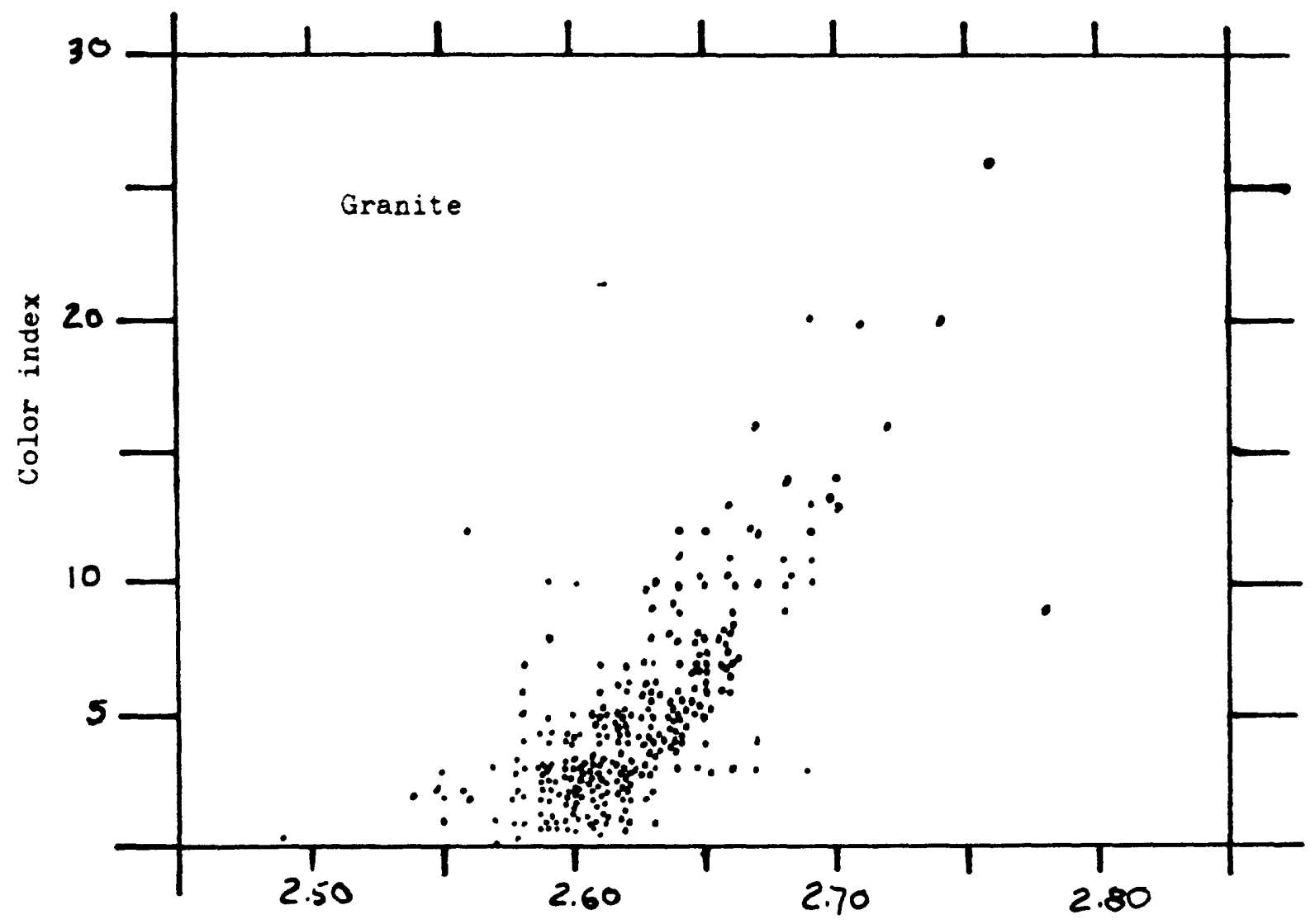

Specific gravity in grams/cc 3

Figure 3-B 


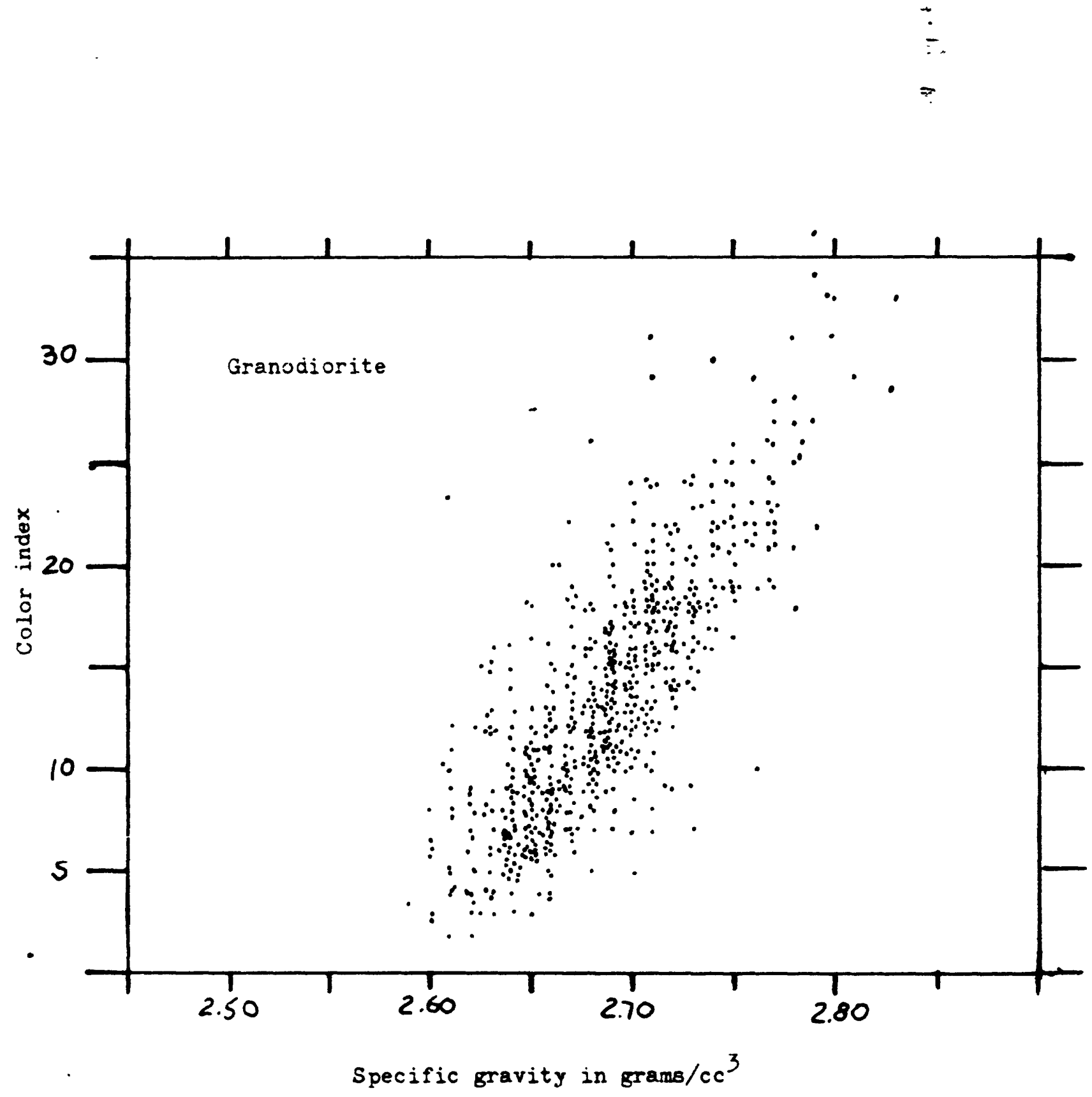

Figure $3-C$ 


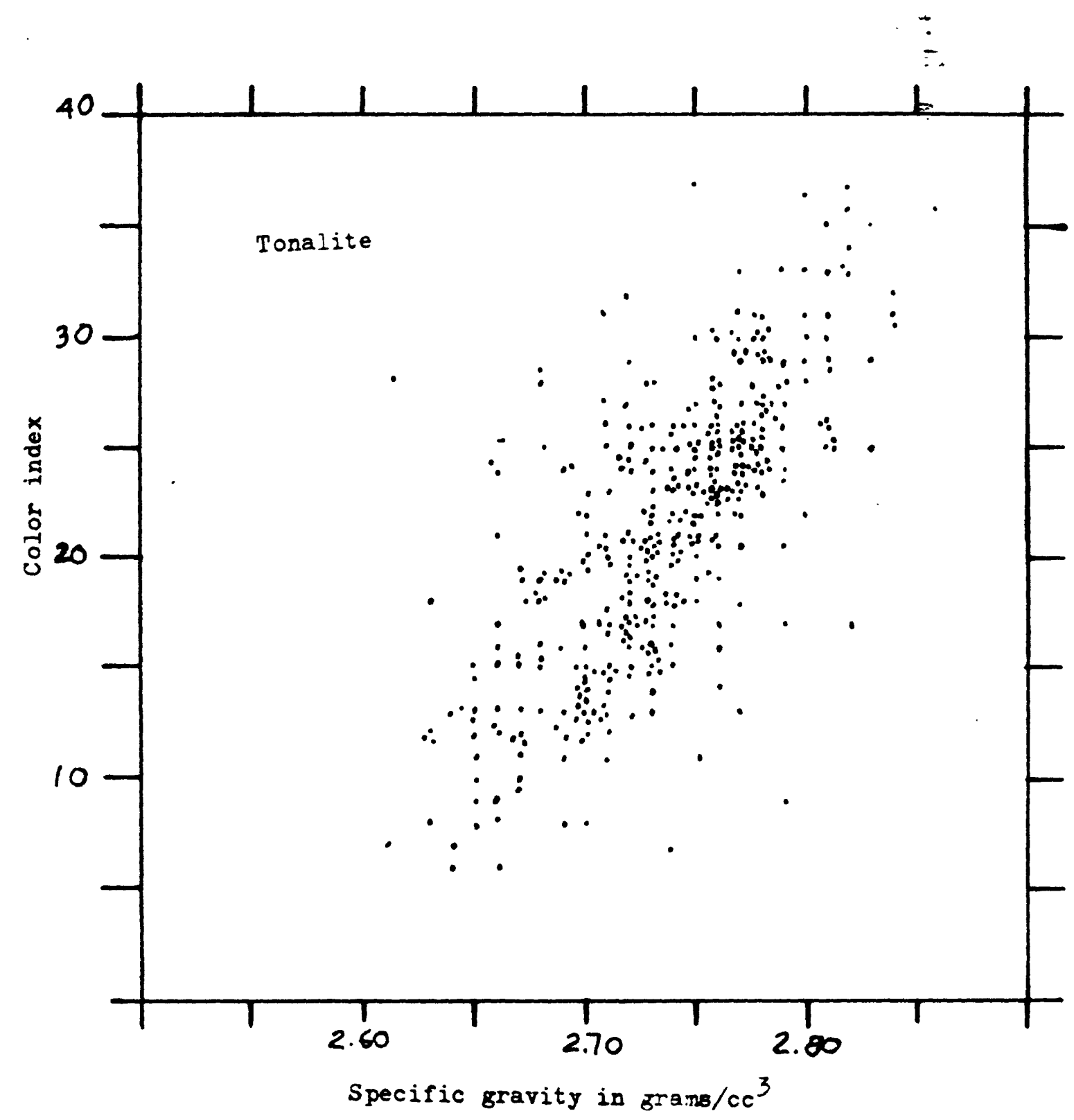

Figure 3-D 


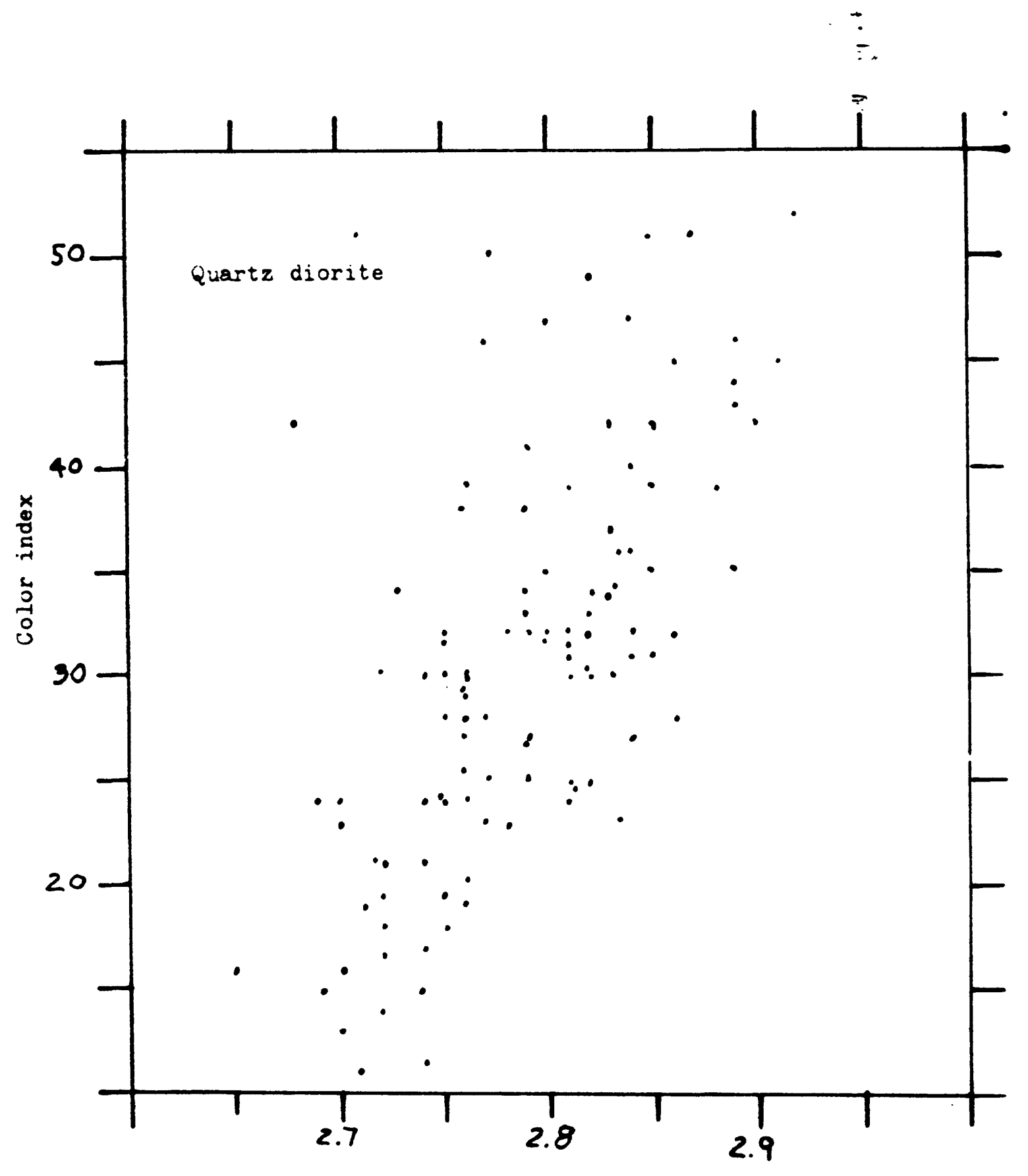

Specific gravity in grams/cc ${ }^{3}$

Figure 3-E

$$
-24-
$$




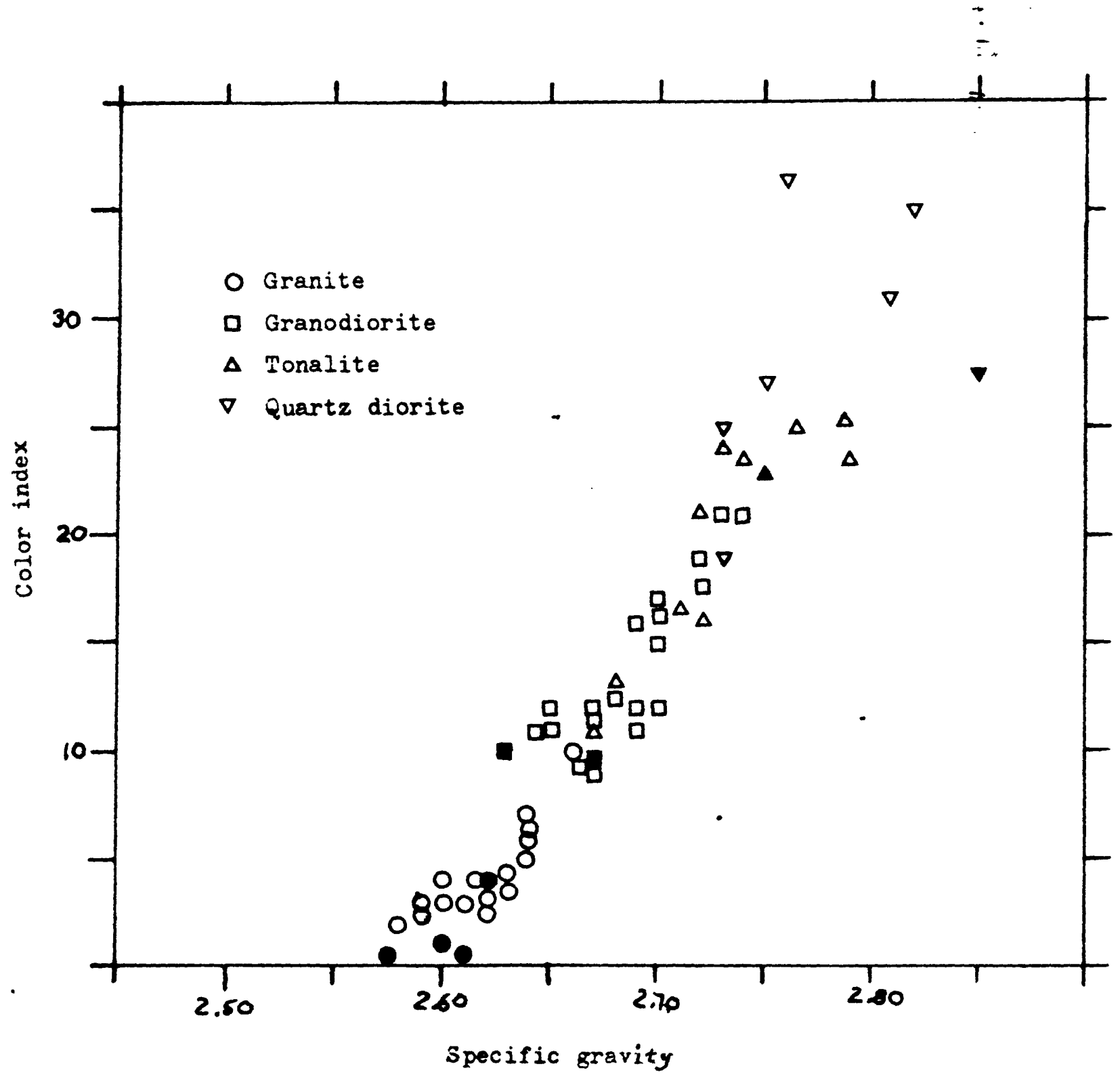

Figure 4. Average specific gravity plotted against average color index for each granitic unit of the southern Sierra Nevada. (solid symbols, units with fewer than 5 samples)

$$
-25-
$$



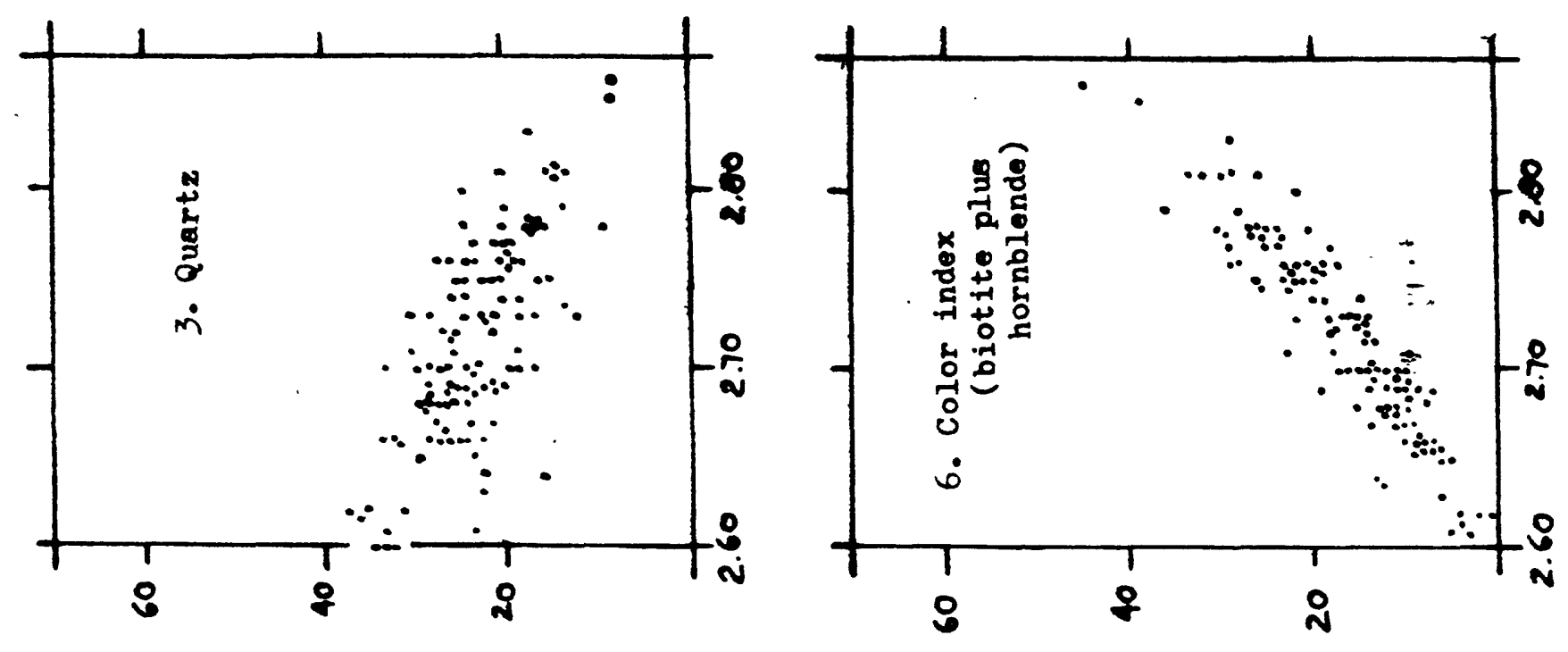

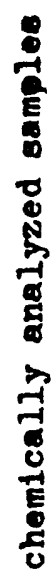
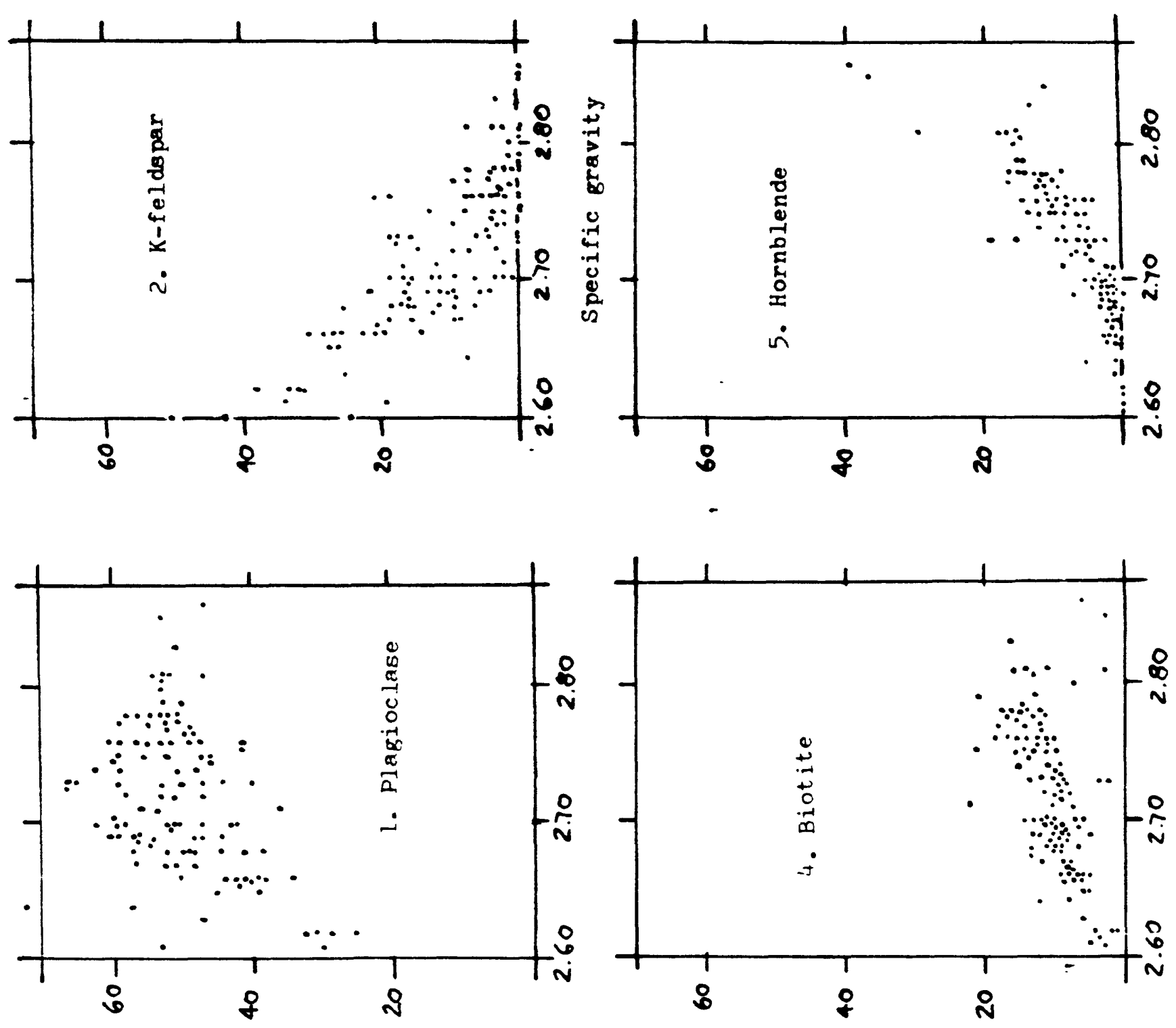

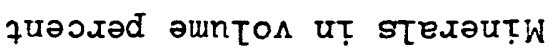




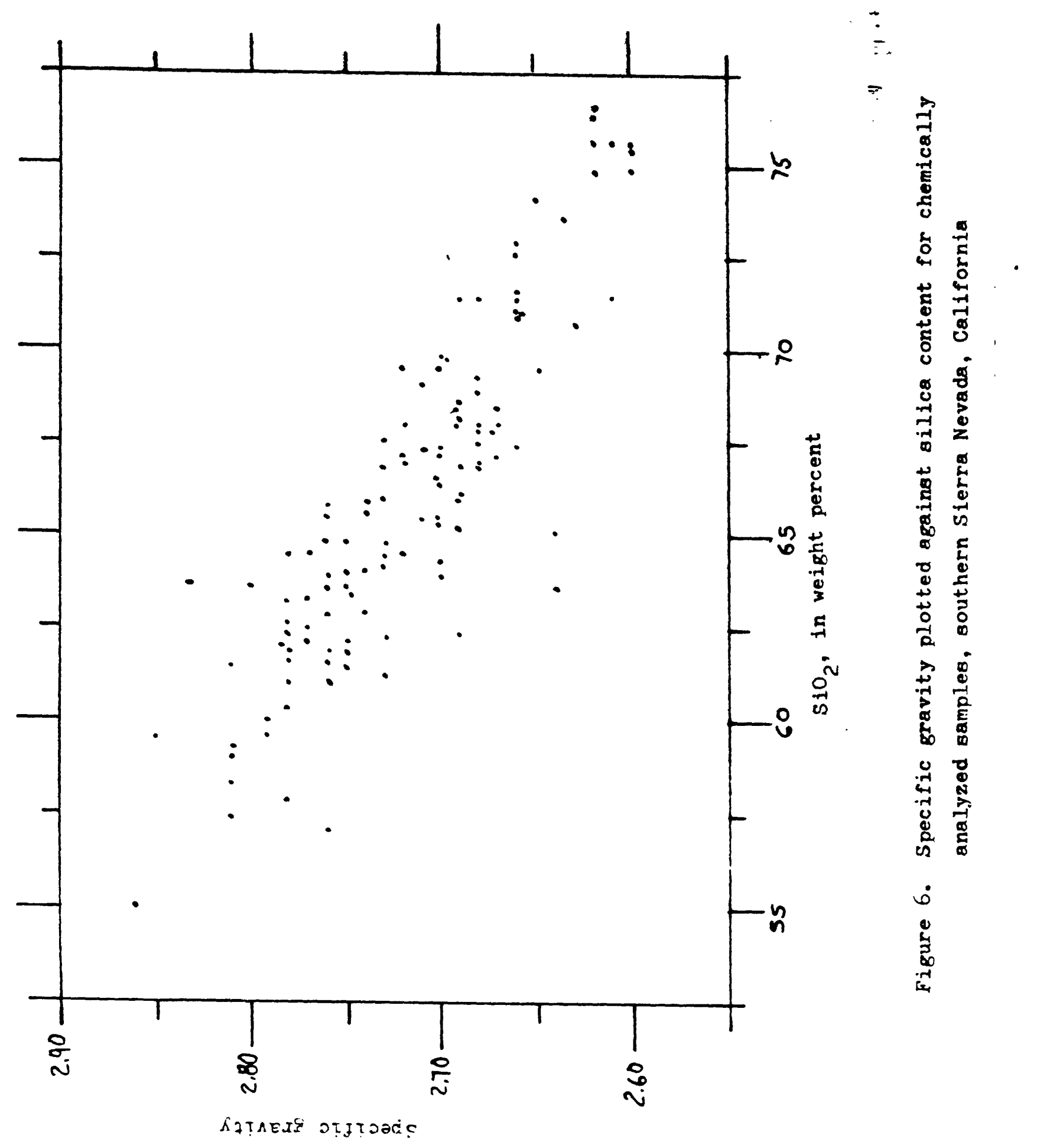

27 
Table 1. Supplement to specific gravity determinations recorded in U.S.G.S Open-File Report 87-373 (Ross, 1987). Table keyed to units and modal samples in that report.

\begin{tabular}{|c|c|c|c|c|c|}
\hline Unit & $\begin{array}{l}\text { Sample } \\
\text { number } \\
\text { ranite }\end{array}$ & $\begin{array}{l}\text { Specific } \\
\text { gravity } \\
(2 .+ \text { ) }\end{array}$ & Unit & $\begin{array}{l}\text { Sample } \\
\text { number }\end{array}$ & $\begin{array}{c}\text { Specific } \\
\text { gravity } \\
(2 .+)^{\prime}\end{array}$ \\
\hline \multirow{3}{*}{$\begin{array}{l}\text { Baker } \\
\text { Point }\end{array}$} & $4625 R$ & 63 & \multirow{11}{*}{$\begin{array}{l}\text { Kern } \\
\text { Biven.) }\end{array}$} & $5120 B$ & 66 \\
\hline & 5281 & 62 & & 5266 & 65 \\
\hline & 5283 & 63 & & 5268 & 64 \\
\hline \multirow[t]{3}{*}{ Black litn } & 5506 & 56 & & 5272 & 69 \\
\hline & 5512 & 55 & & 5274 & 63 \\
\hline & 5556 & 57 & & 5279 & 70 \\
\hline \multirow{10}{*}{$\begin{array}{l}\text { Bob } \\
\text { Rabbit }\end{array}$} & 5599 & 65 & & $5286 \mathrm{C}$ & 72 \\
\hline & 5600 & 66 & & $5286 \mathrm{R}$ & 76 \\
\hline & 5602 & 60 & & 5288 & 74 \\
\hline & 5604 & 66 & & $5290 \mathrm{R}$ & 70 \\
\hline & $5606 A$ & 63 & & 5297 & 70 \\
\hline & 5638 & 64 & \multirow{6}{*}{$\begin{array}{l}\text { Long } \\
\text { Meadow }\end{array}$} & 5379 & 64 \\
\hline & 5641 & 64 & & 5408 & 61 \\
\hline & 5643 & 62 & & 5410 & 64 \\
\hline & $5648 A$ & 61 & & 5411 & 64 \\
\hline & $5648 B$ & 67 & & 5413 & 63 \\
\hline \multirow{13}{*}{$\begin{array}{l}\text { Five } \\
\text { Fingers }\end{array}$} & 6204 & 61 & & 5414 & 61 \\
\hline & 6207 & 63 & \multirow{8}{*}{$\begin{array}{l}\text { Noname } \\
\text { Canyon }\end{array}$} & $6442 \mathrm{~A}$ & 59 \\
\hline & 6208 & 66 & & $6448 B$ & 63 \\
\hline & 6380 & 67 & & 6451 & 63 \\
\hline & 6387 & 63 & & 6457 & 62 \\
\hline & 6388 & 65 & & 6468 & 62 \\
\hline & 6405 & 59 & & $6536 \mathrm{C}$ & 60 \\
\hline & 6407 & 68 & & 6538 & 63 \\
\hline & 6415 & 68 & & 6543 & 62 \\
\hline & $6417 \mathrm{~A}$ & 65 & \multirow[t]{6}{*}{ Onyx } & $5315 \mathrm{C}$ & 60 \\
\hline & $6420 B$ & 66 & & 5328 & 64 \\
\hline & $6493 \mathrm{~A}$ & 61 & & 5332 & 65 \\
\hline & 6535 & 66 & & 5678 & 66 \\
\hline \multirow[t]{2}{*}{$\begin{array}{l}\text { Kern } \\
\text { River }\end{array}$} & 5113 & 64 & & 5682 & $62=$ \\
\hline & 51170 & 66 & & 5700 & 65 \\
\hline
\end{tabular}


Table 1 (cont.)

\begin{tabular}{|c|c|c|c|c|c|c|}
\hline Unit & $\begin{array}{l}\text { Sample } \\
\text { number }\end{array}$ & $\begin{array}{l}\text { Specific } \\
\text { gravity } \\
(2 .+ \text { ) }\end{array}$ & Unit & $\begin{array}{l}\text { Sample } \\
\text { number }\end{array}$ & $\begin{array}{c}\text { Speci } \\
\text { grav } \\
\text { (2. }\end{array}$ & $\begin{array}{l}\text { ific } \\
\text { vity }\end{array}$ \\
\hline \multirow{12}{*}{$\begin{array}{l}\text { Onyx } \\
\text { (cont.) }\end{array}$} & 5708 & 59 & & Gra & orite & $\leftarrow$ \\
\hline & 5710 & 65 & \multirow{22}{*}{$\begin{array}{l}\text { A.lder } \\
\text { Creek }\end{array}$} & 5256 & 72 & $=$ \\
\hline & $5719 \mathrm{~A}$ & 62 & & 5259 & 69 & $\Rightarrow$ \\
\hline & $5719 B$ & 62 & & 5261 & 72 & \\
\hline & 6131 & 63 & & 5427 & 67 & \\
\hline & 6152 & 60 & & 5492 & 75 & \\
\hline & 6195 & 61 & & 5499 & 70 & \\
\hline & 6198 & 59 & & 5503 & 75 & \\
\hline & 6236 & 62 & & 5527 & 70 & \\
\hline & 6238 & 65 & & 5530 & 69 & \\
\hline & 6241 & 61 & & 5562 & 74 & \\
\hline & $\mathrm{RWK}-6 \mathrm{~B}$ & 64 & & 5586 & 68 & \\
\hline \multirow{5}{*}{$\begin{array}{l}\text { Portuguese } \\
\text { Pass }\end{array}$} & 5289 & 65 & & 5587 & 72 & \\
\hline & $5571 B$ & 64 & & 5591 & 71 & \\
\hline & 5574 & 66 & & 5705 & 71 & \\
\hline & 5582 & 65 & & 5987 & 73 & \\
\hline & 5595 & 66 & & 6242 & 71 & \\
\hline \multirow{2}{*}{$\begin{array}{l}\text { Robbers } \\
\text { Roost }\end{array}$} & 6392 & 61 & & 6245 & 73 & \\
\hline & 6395 & 61 & & 6249 & 73 & \\
\hline \multirow{3}{*}{$\begin{array}{l}\text { Sand } \\
\text { Canyon }\end{array}$} & $6448 \mathrm{~A}$ & 64 & & 6254 & 78 & \\
\hline & 6450 & 65 & & 6269 & 71 & \\
\hline & $6454 B$ & 60 & & $6272 \mathrm{~A}$ & 73 & \\
\hline \multirow{12}{*}{$\begin{array}{l}\text { Sherman } \\
\text { Pass }\end{array}$} & 5350 & 62 & & 62725 & 72 & \\
\hline & 5382 & 62 & \multirow{11}{*}{$\begin{array}{l}\text { Castle } \\
\text { Rock }\end{array}$} & 5324 & 60 & \\
\hline & 5383 & 63 & & 5327 & 64 & \\
\hline & 5384 & 59 & & 5329 & 62 & \\
\hline & 5387 & 61 & & 5336 & 65 & \\
\hline & 5390 & 62 & & 5355 & 62 & \\
\hline & $5393 A$ & 63 & & 5356 & 68 & \\
\hline & 5400 & 58 & & 5360 & 66 & \\
\hline & & & & 5381 & 64 & \\
\hline & & & & 5391 & 66 & \\
\hline & & & & 5394 & 65 & $=$ \\
\hline & & & & 5395 & 66 & \\
\hline
\end{tabular}


Table I (cont.)

\begin{tabular}{|c|c|c|c|c|c|}
\hline Unit & $\begin{array}{l}\text { Sample } \\
\text { number }\end{array}$ & $\begin{array}{c}\text { Specific } \\
\text { gravity } \\
(2 . \ldots)\end{array}$ & Unit & $\begin{array}{l}\text { Sample } \\
\text { number }\end{array}$ & $\begin{array}{l}\text { Specific } \\
\text { gravity } \\
(2 .\end{array}$ \\
\hline \multirow{29}{*}{$\begin{array}{l}\text { Castle } \\
\text { Rock } \\
\text { (cont.) }\end{array}$} & 5403 & 65 & \multirow{12}{*}{$\begin{array}{l}\text { Deer } \\
\text { Greek.) }\end{array}$} & $6032 A$ & 68 \\
\hline & 5605 & 65 & & $6032 B$ & 70 \\
\hline & 5609 & 69 & & 6050 & 65 \\
\hline & 5644 & 65 & & 6051 & 64 \\
\hline & 5647 & 66 & & 6052 & 64 \\
\hline & 5654 & 65 & & 6053 & 71 \\
\hline & 5656 & 67 & & 6113 & 67 \\
\hline & 5658 & 69 & & 6115 & 64 \\
\hline & 5659 & 69 & & 6116 & 70 \\
\hline & 5665 & 71 & & 6117 & 69 \\
\hline & 5669 & 68 & & 6118 & 68 \\
\hline & 5672 & 66 & & 6119 & 71 \\
\hline & 5675 & 71 & \multirow{3}{*}{$\begin{array}{l}\text { Democrat } \\
\text { Springs }\end{array}$} & 6372 & 69 \\
\hline & 5689 & 67 & & 6374 & 64 \\
\hline & 5691 & 65 & & 6375 & 68 \\
\hline & 5711 & 64 & \multirow{7}{*}{$\begin{array}{l}\text { Evans } \\
\text { Flat }\end{array}$} & 5494 & 70 \\
\hline & $5716 \mathrm{~A}$ & 65 & & 5495 & 69 \\
\hline & 5727 & 64 & & 5496 & 68 \\
\hline & 5730 & 65 & & 5497 & 72 \\
\hline & 5732 & 65 & & 5524 & 70 \\
\hline & $6144 A$ & 68 & & 5526 & 69 \\
\hline & $6184 A$ & 66 & & 5563 & 71 \\
\hline & 6196 & 64 & \multirow{12}{*}{$\begin{array}{l}\text { Hatchet } \\
\text { Peak }\end{array}$} & $5809 A$ & 63 \\
\hline & 6212 & 65 & & $5810 \mathrm{~A}$ & 66 \\
\hline & 6237 & 65 & & $5811 A$ & 65 \\
\hline & 6239 & 69 & & 5816 & 64 \\
\hline & 6401 & 65 & & 5846 & 65 \\
\hline & 6513 & 64 & & 5863 & 67 \\
\hline & 6539 & 63 & & $5865 \mathrm{~A}$ & 68 \\
\hline \multirow{5}{*}{$\begin{array}{l}\text { Deer } \\
\text { Creek }\end{array}$} & $6008 \mathrm{~B}$ & 71 & & 5867 & 65 \\
\hline & 6009 & 71 & & 5868 & 64 \\
\hline & 6010 & 71 & & $5869 A$ & 64 \\
\hline & 6030 & 72 & & $5880 A$ & 74 \\
\hline & 6031 & 69 & & 5881 & 71 \\
\hline
\end{tabular}


Table 1 (cont.)

Unit Sample

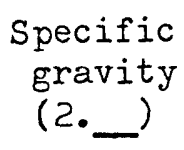

Hatchet

(cont.)

(cont.)

5890

5913A

5914

$5915 B$

Peppermint

Neadow

\section{3}

4995

4996

5000

5001

5033

5034

$5302 \mathrm{~B}$

5814

5815

5819

5820

5823

5824

5825

5827

5829

5831

5833

5834

5835

5838

5841

5849

5852

5854

5855

5862

5866

5873

5875
65

69

73

69

67

69

66

70

67

77

77

71

64

64

60

67

63

66

63

67

66

68

64

65

66

75

67

67

67

67

69

73

70

69

77
Unit

Sample
number

Specific

gravity

(2. )

$\begin{array}{llr}\text { Peppermint } & 5880 \mathrm{~B} & 67 \\ \text { Meadow } & 5883 & : 66 \\ \text { (Cont.) } & & :\end{array}$

(Cont.)

\section{Pine}

Flat

$\frac{5915 A}{5801} \quad \overline{71}$

$5801 R$

71

5802

68

5803

69

5804

68

5885B

68

$5885 \mathrm{R}$

67

$5895 \mathrm{~A}$

74

$5895 B$

74

5897

75

5898

71

5900

66

$5901 B$

72

5902

70

5926

71

5927

72

5929

72

5941

72

5942

67

$5945 \mathrm{~A}$

68

5946

70

5948

72

5949

65

5950

68

5957B

73

5959

70

5960

71

5964

73

5965

66

5967

69

5969

69

5993

69

5995 
Table I (cont.)

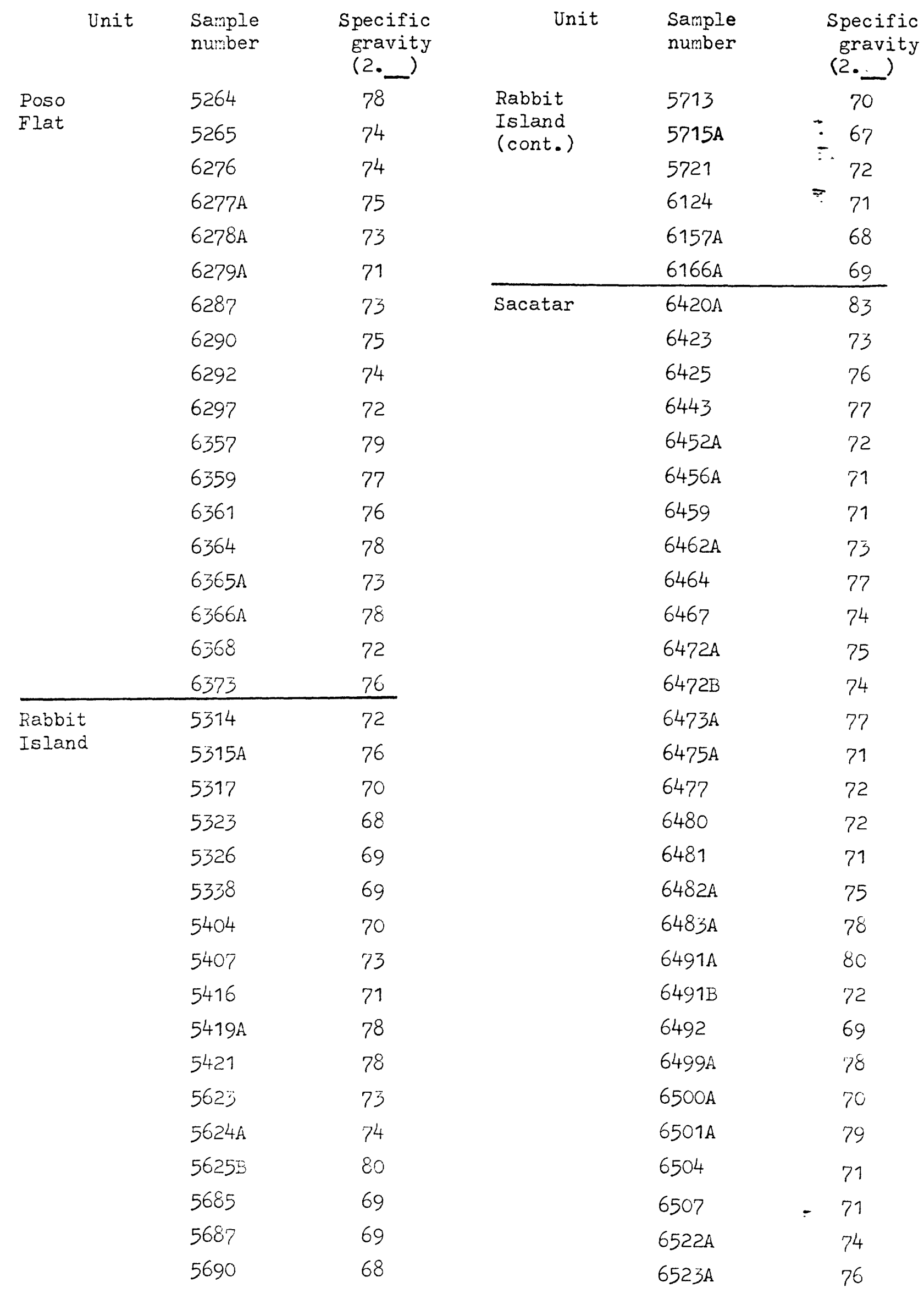


Table I (cont.)

\begin{tabular}{|c|c|c|c|c|c|c|}
\hline Unit & $\begin{array}{l}\text { Sample } \\
\text { number }\end{array}$ & $\begin{array}{l}\text { Specific } \\
\text { gravity }\end{array}$ & Unit & $\begin{array}{l}\text { Sample } \\
\text { number }\end{array}$ & & $\begin{array}{l}\text { Specific } \\
\text { gravity }\end{array}$ \\
\hline \multirow{2}{*}{$\begin{array}{l}\text { Sacatar } \\
\text { (cont.) }\end{array}$} & 6526 & 70 & \multirow{21}{*}{$\begin{array}{l}\text { Carver- } \\
\text { Bowen } \\
\text { (cont.) }\end{array}$} & 5990 & & 76 \\
\hline & 6537 & 71 & & 5991 & - & 76 \\
\hline \multirow{25}{*}{$\begin{array}{l}\text { Bear Valley } \\
\text { Springs }\end{array}$} & Tonalite & & & 6014 & $\dot{E}$ & 75 \\
\hline & 5430 & 70 & & 6017 & \multirow{18}{*}{$?$} & $50(?)$ \\
\hline & 5432 & 78 & & $6019 A$ & & 79 \\
\hline & 5435 & 75 & & $6020 \mathrm{~A}$ & & 81 \\
\hline & 5438 & 74 & & 6028 & & 80 \\
\hline & 5440 & 76 & & 6029 & & 83 \\
\hline & 5445 & 74 & & 6036 & & 68 \\
\hline & 6296 & 67 & & $6037 \mathrm{~A}$ & & 76 \\
\hline & 6299 & 76 & & 6039 & & 79 \\
\hline & 6300 & 78 & & $6040 \mathrm{~A}$ & & 76 \\
\hline & 6302 & 78 & & 6078 & & 83 \\
\hline & 6322 & 77 & & $6079 A$ & & 78 \\
\hline & $6322 R$ & 77 & & 6082 & & 84 \\
\hline & 6326 & 72 & & 6094 & & 79 \\
\hline & 6329 & 76 & & 6101 & & 84 \\
\hline & 6332 & 73 & & 6110 & & 77 \\
\hline & 6335 & 75 & & 6111 & & 75 \\
\hline & 6336 & 78 & & $6114 \mathrm{~A}$ & & 76 \\
\hline & 6340 & 74 & & 7275 & & 81 \\
\hline & 6341 & 76 & \multirow{14}{*}{$\begin{array}{l}\text { Dunlap } \\
\text { Neadow }\end{array}$} & $500 ?$ & & 79 \\
\hline & 6342 & 77 & & 5008 & & 79 \\
\hline & 6356 & 76 & & 5010 & & 81 \\
\hline & 6369 & 80 & & 5015 & & 73 \\
\hline & 6371 & 78 & & $5015 R$ & & 72 \\
\hline & 6376 & 74 & & 5285 & & 81 \\
\hline \multirow{8}{*}{$\begin{array}{l}\text { Carver- } \\
\text { Bowen }\end{array}$} & $5976 \mathrm{~A}$ & 81 & & 5291 & & 70 \\
\hline & 5978 & 72 & & 5292 & & 76 \\
\hline & 5979 & 81 & & 5293 & & 75 \\
\hline & 5980 & 83 & & 5304 & & 82 \\
\hline & 5981 & 78 & & 5305 & & 73 \\
\hline & $5983 \mathrm{~A}$ & 77 & & 5573 & \multirow{3}{*}{$=$} & 74 \\
\hline & 5988 & 82 & & 5575 & & 78 \\
\hline & 5980 & 86 & & 5577 & & 73 \\
\hline
\end{tabular}


Table I (cont.)

Unit

Sample
number

Specific

gravity

(2._)

Dunlap

Meadov!

(cont.)

$\begin{array}{ll}5581 & 78 \\ 5584 & 75 \\ 5805 & 76 \\ 5807 & 75 \\ 5870 A & 79 \\ 5870 B & 79\end{array}$

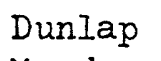

Meadow

(cont.)

Sample

Specific

number

gravity

$5870 \mathrm{~B}-79$

$5871 \quad 81$

$5872 \quad 80$

$5884 \quad 82$

$5885 \mathrm{~A} \quad 80$

5885-1 80

5886A 77

$5887 \quad 76$

5916A $\quad 78$

$5918 \quad 75$

$5922 \quad 77$

$5924 \quad 78$

$5930 \quad 76$

$5931 \quad 78$

$5932 \quad 77$

$5933 \quad 77$

593775

5938A 77

5939A $\quad 77$

5939B $\quad 76$

$5940 \quad 77$

$5952 \quad 71$

$5953 \quad 70$

$5954 \quad 77$

$5962 \quad 76$

$5974 \quad 75$

5975A $\quad 76$

$5994 \quad 71$

$5996 \quad 76$

\begin{tabular}{|c|c|c|}
\hline & 6000 & 72 \\
\hline & 6002 & 79 \\
\hline & 6004 & 78 \\
\hline & $6005 A$ & 77 \\
\hline Fountain & 6024 & 75 \\
\hline Springs & $6055 A$ & 74 \\
\hline & 6056 & 72 \\
\hline & $6058 \mathrm{~A}$ & 74 \\
\hline & 6059 & 71 \\
\hline & 6062 & 73 \\
\hline & 6065 & 70 \\
\hline & 6066 & 72 \\
\hline & 6084 & 72 \\
\hline & 6085 & 73 \\
\hline & 6105 & 75 \\
\hline & 6106 & 73 \\
\hline & 6107 & 65 \\
\hline Walt & 6061 & 73 \\
\hline Klein & 6067 & 71 \\
\hline & $6096 \mathrm{~A}$ & 70 \\
\hline & 6070 & 66 \\
\hline & 6072 & 69 \\
\hline & 6073 & 71 \\
\hline & $6074 B$ & 74 \\
\hline & 6075 & 73 \\
\hline & 6076 & 67 \\
\hline & 6077 & 70 \\
\hline & 6088 & 70 \\
\hline & 6096 & 76 \\
\hline & 6280 & 71 \\
\hline & $6281 A$ & $75^{-}$ \\
\hline
\end{tabular}


Table 1 (cont.)

$$
\text { Unit Sample }
$$

Walt
Klein
(cont.)
Specific

gravity

(2. )

67

69

73

73

72

70

70

74

71

70

6346A

73

6353

6354

6355

72

74

RWK-I-RA

RWK-2

78

69

Wofford

Heights

5456

$5457 \mathrm{~B}$

77

76

$5458 \mathrm{~B}$

82

5460

81

5507

84

5513

78

5514

76

5534

Zumvalt

6120

75

73

6121

74

6123

78

Quartz diorite

Caliente

3

2

4

9

7

2

1

$5441 \mathrm{~A}$

77

$5787 \mathrm{~A}$

71

$5790 \mathrm{~B}$

92

5791

76

5793
Unit

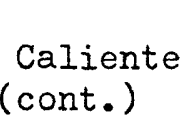

Caliente
(cont.)

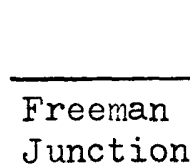

Sample

number

Junction

5798

5799B

5800

6202
$6205 A$

6398A

6433

6434

$6438 \mathrm{~A}$

6439

$6532 \mathrm{~A}$

\begin{tabular}{lll} 
& $6532 \mathrm{~A}$ & 83 \\
\hline Rhymes & 6255 & 86 \\
Campground & 6262 & 84 \\
\hline Walker & $5735 \mathrm{~A}$ & 72 \\
Pass & $5735 \mathrm{~B}$ & 72 \\
& $5735 \mathrm{C}$ & 75 \\
& 6136 & 70 \\
& 6149 & 75 \\
& 6169 & 71 \\
& 6171 & 74 \\
& $6178 \mathrm{~A}$ & 69 \\
6179 & 74 \\
& $6193 \mathrm{~A}$ & 77 \\
6220 & 76 \\
& 6226 & 70 \\
& 6391 & 73 \\
& 6402 & 74 \\
6498 & 73 \\
\hline
\end{tabular}

68

76

75

74

70

65

69

75

76

72

Specific

gravity

(2.__ 
Table 2. Computed specific grarity, by rock type, using modes and average mineral specific gravity

Modal average

$\begin{array}{lcccccc} & \text { Plag } & \text { K-feld } & \text { Qtz } & \text { Biot } & \text { Hbnd } & \text { Computedaspecific } \\ \text { Granite } & 35 & 32 & 31 & 4 & - & 2.64 \\ \text { Granodiorite } & 49 & 13 & 25 & 10 & 3 & 2.70 \\ \text { Tonalite } & 54 & 4 & 21 & 12 & 9 & 2.76 \\ \text { Quartz diorite } & 58 & 2 & 12 & 10 & 18 & 2.81\end{array}$

Weighted modal average

$\begin{array}{llccccc}\text { Granite } & 34 & 31 & 30 & 5 & - & 2.65 \\ \text { Granodiorite } & 49.5 & 14 & 23 & 10.5 & 3 & 2.70 \\ \text { Tonalite } & 54 & 3 & 22 & 12 & 9 & 2.76 \\ \text { Quartz diorite } & 58 & 2 & 13 & 8 & 19 & 2.80\end{array}$

Specific gravity values used for mineralo

Source

Plagioclase

Deer, Howie, and Zussman, 1965

Oligoclase

2.65

Andesine

2.67

$\mathrm{K}$-feldspar

2.58

Quartz

2.65

Biotite

3.03

Hornblende
11

".

11

$"$

Dodge and Ross, 1971

18

O Taking into account the area of distribution of the various granitic units 
Table 3 - Comparison of average measured and computed specific gravity for selected granitic units

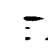

?

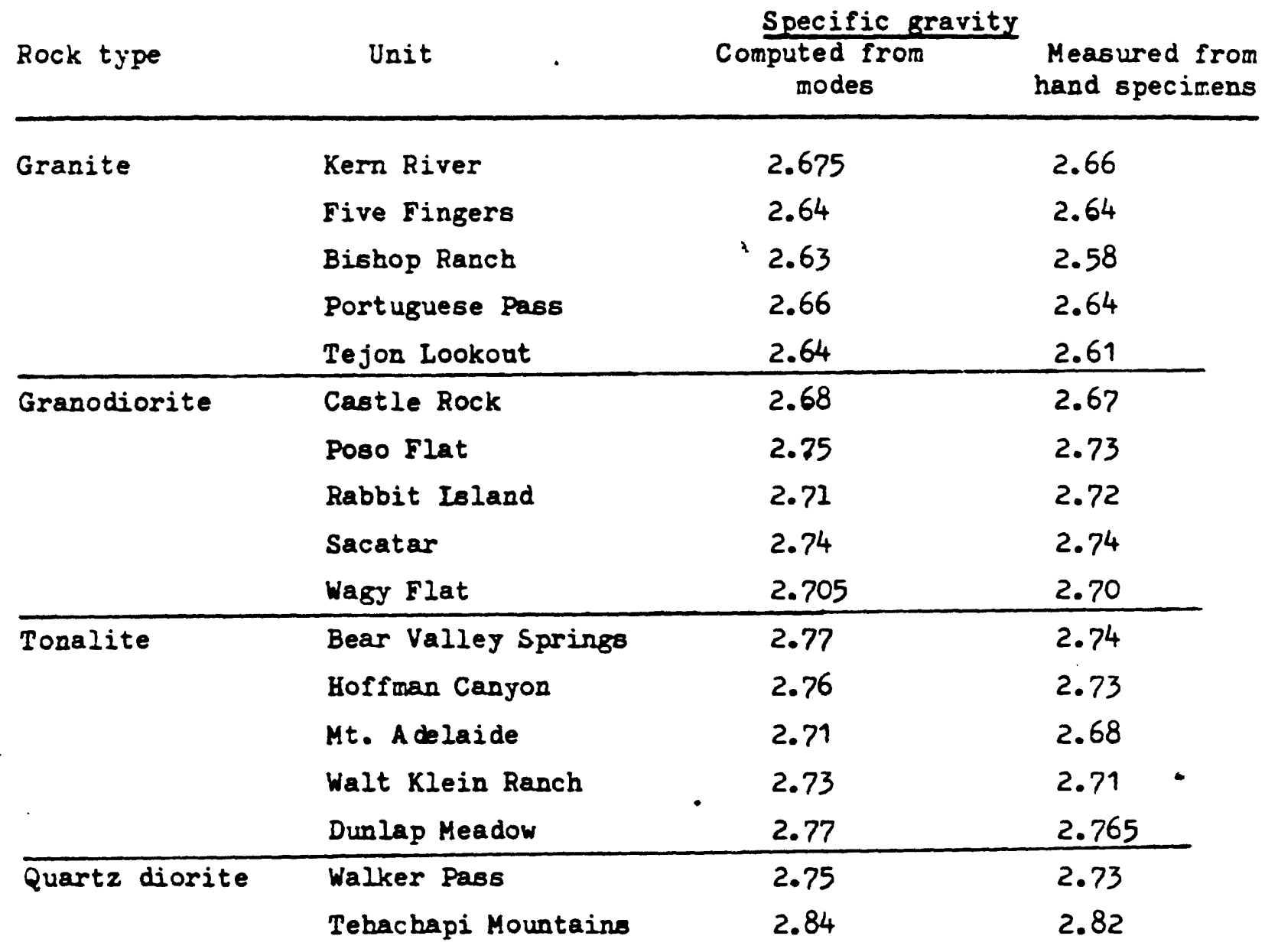

